\title{
Characterisation of bioaerosol emissions from a Colorado pine forest: results from the BEACHON-RoMBAS experiment
}

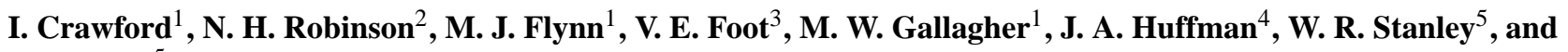 \\ P. H. Kaye ${ }^{5}$ \\ ${ }^{1}$ Centre for Atmospheric Science, SEAES, University of Manchester, Manchester, UK \\ ${ }^{2}$ Met Office, Exeter, UK \\ ${ }^{3}$ Defence Science and Technology Laboratory, Porton Down, Salisbury, SP4 0JQ, UK \\ ${ }^{4}$ Department of Chemistry \& Biochemistry, University of Denver, 2190 E. Illif Ave., Denver, CO, 80208, USA \\ ${ }^{5}$ Science and Technology Research Institute, University of Hertfordshire, Hatfield AL10 9AB, UK \\ Correspondence to: I. Crawford (i.crawford@manchester.ac.uk)
}

Received: 26 November 2013 - Published in Atmos. Chem. Phys. Discuss.: 27 January 2014

Revised: 15 July 2014 - Accepted: 16 July 2014 - Published: 25 August 2014

\begin{abstract}
The behaviour of primary biological aerosols (PBAs) at an elevated, un-polluted North American forest site was studied using an ultra violet-light induced fluorescence (UV-LIF) measurement technique in conjunction with hierarchical agglomerative cluster analysis (HA-CA). Contemporaneous UV-LIF measurements were made with two wide-band integrated bioaerosol spectrometers, WIBS-3 and WIBS-4, which sampled close to the forest floor and via a continuous vertical profiling system, respectively. Additionally, meteorological parameters were recorded at various heights throughout the forest and used to estimate PBAP (Primary Biological Aerosol Particle) fluxes. HA-CA using data from the two, physically separated WIBS instruments independently yielded very similar cluster solutions.

All fluorescent clusters displayed a diurnal minimum at midday at the forest floor with maximum concentration occurring at night. Additionally, the number concentration of each fluorescent cluster was enhanced, to different degrees, during wet periods. A cluster that displayed the greatest enhancement and highest concentration during sustained wet periods appears consistent with behaviour reported for fungal spores. A cluster that appears to be behaviourally consistent with bacteria dominated during dry periods. Fluorescent particle concentrations were found to be greater within the forest canopy than at the forest floor, indicating that the canopy was the main source of these particles rather than the minimal surface vegetation, which appeared to contribute little to overall PBA concentrations at this site.
\end{abstract}

Fluorescent particle concentration was positively correlated with relative humidity ( $\mathrm{RH})$, and parameterisations of the aerosol response during dry and wet periods are reported. The aforementioned fungal spore-like cluster displayed a strong positive response to increasing $\mathrm{RH}$. The bacteria-like cluster responded more strongly to direct rain-fall events than other PBA types. Peak concentrations of this cluster are shown to be linearly correlated to the log of peak rainfall rates.

Parallel studies by Huffman et al. (2013) and Prenni et al. (2013) showed that the fluorescent particle concentrations correlated linearly with ice nuclei (IN) concentrations at this site during rain events. We discuss this result in conjunction with our cluster analysis to appraise the candidate IN.

\section{Introduction}

Primary biological aerosols (PBAs) are a diverse and complex classification of aerosols usually defined as those aerosols that are directly introduced to the atmosphere in the condensed phase and are composed of both viable and non-viable classes of potentially regenerative biological material (Després et al., 2012). PBAs generally present varying concentrations depending on biogeographical location, but on average represent only minor fractions (by number) of total aerosols, other than in remote tropical 
rainforests or ecosystems not impacted by anthropogenic pollution. Generic classes of PBAs include the following: viruses $(0.01-0.3 \mu \mathrm{m})$; bacteria and bacteria agglomerates $(0.1-10 \mu \mathrm{m})$; fungal and plant spores $(1-30 \mu \mathrm{m})$; pollen $(5-$ $100 \mu \mathrm{m})$; and includes plant, insect, and animal fragments as well as liquids and coatings co-emitted with many microorganisms (Després et al., 2012; Elbert et al., 2007). The focus of the work presented here is to provide a quantitative estimate of PBA number concentrations to the ongoing discussions regarding how much PBAs indirectly influence regional hydrological cycles through aerosol cloud indirect effects. It has been shown that climatological factors, including temperature and rainfall, play key roles in controlling the abundance of many PBA classes. Gange et al. (2011) and Kauserud et al. (2010) used long term (> $50 \mathrm{yr}$ ) observational data sets to suggest that fungal germination range and frequency, growth rates and host colonisation diversity has increased in response to climate warming. Observations of bioaerosol emissions also have relevance for regenerative pathogen emission and dispersal of plant, animal and human disease factors (Tack et al., 2014). Jacobson and Streets (2009) used a global model with very detailed bioaerosol emission processes to show that PBAs such as terrestrial bacteria and spores (but not pollen) are likely to increase in response to climate warming. However, diversity change scenarios remain uncertain due to the limited biogeographical emission information for many PBAs. Fröhlich-Nowoisky et al. (2012), for example, showed that geo-biodiversity distributions displayed a much lower proportion of Basidiomycota in marine environments compared to Ascomycota fungi in terrestrial forest systems than had been previously assumed.

A growing body of work has recently identified and quantified PBAs in rainfall and in hail, while airborne studies have identified PBAs in cloud ice crystal residuals collected in situ (Christner et al., 2008; Möhler et al., 2007; Pratt et al., 2009; Pope, 2010; DeMott et al., 2010; Levin et al., 2012; Šantl Temkiv et al., 2013; DeLeon-Rodriguez et al., 2013). Certain PBAs have been shown to act as highly efficient ice nuclei (IN) at relatively warm temperatures (e.g. Diehl et al., 2001, 2002; Haga et al., 2013; Möhler et al., 2008a; Morris et al., 2004, 2013; Pummer et al., 2013). However, based on the limited, currently available observations, bioaerosol concentrations are generally considered to be negligible contributors to ice formation processes at temperatures below $-30^{\circ} \mathrm{C}$ (Cziczo et al., 2013). Their role at warmer temperatures as IN in mixed phase clouds and as cloud condensation nuclei (CCN) for regional scale processes remains to be fully quantified. Initial model studies have shown that the concentrations of PBAs are likely to be too low to influence net global cloud radiative impacts significantly (Hoose et al., 2010; Sesartic et al., 2013), however their regional influence on clouds and precipitation may be significantly more important than estimated due to the initiation of secondary ice production (Crawford et al., 2012;
Morris et al., 2013; Pöschl et al., 2010). The recent aircraft study by DeLeon-Rodriguez et al. (2013) also suggests that tropospheric microbiome concentrations are likely underestimated in global and regional models and particularly when influenced by strong convective uplift, as in the storm outflows they sampled. They also show that a large fraction of the PBA population detected at $\sim 6-8 \mathrm{~km}$ was dominated by bacteria and not fungal spores and appeared to be derived from plant sources and not soil sources. Much of the current uncertainty in the role bioaerosols play in the climate system is due to the lack of coherent, systematic studies quantifying different bio-particle detection methodologies, particularly on timescales relevant to the atmospheric boundary layer (see e.g. Jacobson and Streets, 2009). This has lead to poor quantification in both overall emission fluxes and in particular fluxes discriminated by PBA type. There is also debate concerning the reliability of detection methodologies, suggesting that conclusions, in many cases, can be biased by use of different procedures (Smith and Griffin, 2013). Responses to such criticisms usually focus on the heterogeneity in PBA sources that are difficult to capture using traditional bioaerosol sampling methods and the impact of different meteorological factors in different bio-geographical environments. Whilst this is an ongoing area of debate and realtime discrimination and quantification remains a significant technical problem, investigations continue to elucidate possible feedback pathways to inform model sensitivity studies for regional and global models that now include PBA emissions (Després et al., 2012; Forster et al., 2007; Heald and Spracklen, 2009; Hummel et al., 2014; Matthias-Maser and Jaenicke, 1995; Jacobson and Streets, 2009). Various studies have emphasised that PBAs may play key roles in the evolution of unperturbed tropical rainforests and their associated ecosystems (Prenni et al., 2009; Pöschl et al., 2010; Pöhlker et al., 2012), but it is only recently that studies have suggested a similar importance for maintenance of boreal and semi-arid forest ecosystems where deforestation susceptibility may impact regional sources of $\mathrm{CCN}$ and IN and hence precipitation patterns in a warming climate (Morris et al., 2014).

As part of this study we report on observations of fluorescent particle concentrations made during a field campaign in an elevated forest in a rural, semi-arid region of Colorado using a portable, continuous multi-wavelength, UV-light induced fluorescence (UV-LIF) aerosol spectrometer. By using a hierarchical agglomerative cluster analysis approach (Robinson et al., 2013) we are able to statistically discriminate between different clusters of observed particles, showing their different diurnal cycles and vertical concentration profiles below and within the forest canopy. We analysed the response of the different clusters to meteorological factors, focusing on rainfall and relative humidity. Here we present parameterisations of rainfall- and $\mathrm{RH}$ - induced concentration enhancements for those particle clusters most affected by these processes and discuss these observations with respect to contemporaneous observations of IN concentrations 
reported recently for the same study (Huffman et al., 2013; Prenni et al., 2013; Tobo et al., 2013).

\section{The regional BEACHON-RoMBAS experiment}

The western United States of America has experienced a significant reduction in precipitation over the last half century, which some have attributed to increased anthropogenic activities (Barnett et al., 2008). It is therefore important to quantify our understanding of aerosol-cloud feedback sensitivity to both natural biogenic and anthropogenic mechanisms influencing the evolution of long-term hydrological cycles in this region. One project designed to investigate these processes was the Bio-hydro-atmosphere interactions of Energy, Aerosols, Carbon, $\mathrm{H}_{2} \mathrm{O}$, Organics and Nitrogen - Rocky Mountain Biogenic Aerosol Study project (BEACHON-RoMBAS) sponsored by the US National Centre for Atmospheric Research. The project took place between 20 June 2011 and 23 July 2011 in the Manitou Experimental Forest Observatory (MEFO), located $35 \mathrm{~km}$ northwest of Colorado Springs, Colorado, USA (Kim et al., 2010; Ortega et al., 2014). The measurement site is located in a rural, montane ponderosa pine forest located at an elevation between 2286 and $2370 \mathrm{~m}$ and centred at latitude $39^{\circ} 06^{\prime} 02^{\prime \prime} \mathrm{N}$, and longitude $105^{\circ} 06^{\prime} 05^{\prime \prime} \mathrm{W}$. Full details of the experimental infrastructure and background climatology can be found at http://cires.colorado.edu/ jimenez-group/wiki/index.php/BEACHON-RoMBAS; http: //web3.acd.ucar.edu/beachon/ and other references that are part of this special issue. The study location is considered representative of the semi-arid forest regions of the western USA. Key aims of the experiment were to assess the importance of these forests as sources of primary biological aerosol and secondary organic aerosol (SOA), and their potential influence on processes linked to the regional hydrological cycle and ecosystem maintenance. All times are reported in Mountain Standard Time (MST).

\subsection{Experiment site description}

Sampling was conducted at two sites; the Tower A ("chemistry tower") site was located at $39^{\circ} 6^{\prime} 3.65^{\prime \prime} \mathrm{N}$, $105^{\circ} 6^{\prime} 10.30^{\prime \prime} \mathrm{W}$, and the Tower B ("micrometeorological tower") site was located approximately $300 \mathrm{~m}$ away at $39^{\circ} 6^{\prime} 6.24^{\prime \prime} \mathrm{N}, 105^{\circ} 6^{\prime} 16.18^{\prime \prime} \mathrm{W}$. Access to the sites and internal dirt road was restricted and carefully monitored to avoid contamination issues. A description of the sites and the main aerosol instrumentation employed can be found in Ortega et al. (2014) and Huffman et al. (2013), and the supplementary material therein. In this paper we will focus on the behaviour of UV-fluorescent particles, which are inferred to be mainly biological in origin, as a function of height within the forest and in response to meteorological factors.
Single particle UV-light induced fluorescence (UV-LIF) signatures were determined using two wideband integrated bioaerosol spectrometers (WIBS, Kaye et al., 2005), an early generation (WIBS-3) and an improved version (WIBS-4). The differences between the two instruments are described in detail below and by Robinson et al. (2013). Collocated with the NCAR (National Centre for Atmospheric Research) turbulence, radiation and rainfall profile system the WIBS-3 was located next to Tower B. It sampled air continuously at $1.3 \mathrm{~m}$ above the forest floor via a $0.5 \mathrm{~m}$ vertical length stainless steel inlet (outer diam. $0.25^{\prime \prime}$ ) which was protected by a rain shroud. Data from the WIBS-3 was used as the surface reference data for measurements made by the WIBS4 using an identical inlet and to allow comparison with earlier WIBS-3 data sets which have been reported from other forest ecosystems, e.g. Gabey et al. (2010). WIBS-4 was used to conduct periodic vertical profile measurements at Tower A (see below). Meteorological measurements were also made of temperature and relative humidity (Rotronics HMP-100), solar radiation (long and short-wave, Kipp and Zonen), wind speed, direction and turbulence (Gill Solent UK, sonic anemometer). We have also used the NCAR core meteorological and turbulence profile data sets from Towers A and B for consistency with other published data sets from this project.

The WIBS-4 was installed at tower A together with temperature and relative humidity sensors (Rotronics HMP-100) in an enclosure, as well as with a total aerosol counter (GRIMM Model 1.108, particle diameter detection range, $\left.0.5<D_{\mathrm{p}}<20 \mu \mathrm{m}\right)$. The latter was used to quality control the total aerosol concentrations reported by the WIBS-4. The inlet configuration for both instruments was the same. The instrument enclosure was then automatically raised and lowered by a programmable, computer-controlled winch between heights of $3 \mathrm{~m}$ and $20 \mathrm{~m}$ up the side of the tower, providing measurements below, within, and above the average $\sim 10-20 \mathrm{~m}$ tree canopy. Ascending profiles paused regularly at eight stages and took typically $45 \mathrm{~min}$. Descending profiles were continuous and took approximately $3 \mathrm{~min}$. Depending on reported real-time results the WIBS- 4 was occasionally left at fixed heights for periods up to $2.5 \mathrm{~h}$ for more detailed investigations. The ponderosa pine forest had a canopy height of $19 \mathrm{~m}$ and a leaf area index $(\mathrm{LAI})=1.9$. The forest presented minimal undergrowth, is influenced predominately by southwest, unpolluted air masses and rarely impacted by air masses influenced by anthropogenic emissions (Kim et al., 2010; Ortega et al., 2014). The lack of extensive undergrowth at the site should be noted as this is important for the interpretation of the cluster solutions presented below as well as the vertical UV-LIF particle concentration profiles observed. 


\subsection{WIBS UV-LIF instrumentation}

A full technical description of the original WIBS measurement principles and its development is described by Kaye et al. (2005); Foot et al. (2008); Gabey (2011) and Stanley et al. (2011). In the WIBS-3 instrument used here ambient air is sampled at typically $2.38 \mathrm{~L} \mathrm{~min}^{-1}$ with $10 \%$ of the total as aerosol flow drawn through a $1.2 \mathrm{~mm}$ (inner diam.) tube to generate a single in-line aerosol beam intersecting a welldefined optical sensing region. The WIBS-4 used in this case sampled $1 \mathrm{~L} \mathrm{~min}^{-1}$ of the $2.38 \mathrm{~L} \mathrm{~min}^{-1}$ total flow. The remainder of the flow is filtered and used as a sheath flow to stabilise the aerosol beam and minimise possible detrainment contamination of the optical surfaces within the scattering chamber. Single particles passing through the sensing region intercept a $635 \mathrm{~nm}$ diode laser beam, and the elastically scattered forward and sideways intensity is measured. A lookup table based on a standard Mie scattering model (Kaye et al., 2005 ) is used to convert the forward to side-scatter intensity ratio to optical diameter based on the instrument's response to NIST (National Institute of Standards and Technology) calibration polystyrene latex (PSL) spheres.

The WIBS- 3 and WIBS- 4 utilise a quadrant detector to measure the scattered intensity. The signal from each component quadrant is used to calculate an "average" optical diameter over the four scattering solid angles. In addition the standard deviation between the four signal intensities is used to provide a particle asymmetry factor $\left(A_{\mathrm{f}}\right)$ as a proxy of particle morphology. $A_{\mathrm{f}}$ is reported in arbitrary units (a.u) and is based on measurements with calibration particles with different aspect ratios. $A_{\mathrm{f}}$ ranges between $8-10$ for near spherical particle and 80-100 for a rod- or fibre-like particles. The detectable particle "average optical diameter" range for WIBS-3 is $0.5<D_{\mathrm{o}}<20 \mu \mathrm{m}$, with a $50 \%$ detection at $D_{\mathrm{p} 50}$ $0.8 \mu \mathrm{m}$ (Gabey, 2011). The WIBS size range is optimised to sample most airborne bacteria and fungal spores, but only very small pollen. For example, typical geometric mean diameters (GMD) for fungal spores are usually reported to be several microns in diameter, e.g. Aspergillusversicolor and Cladosporiumcladosporioides were reported to be $2.26 \pm 0.17 \mu \mathrm{m}$, and $2.62 \pm 0.12 \mu \mathrm{m}$ respectively (Jung et al., 2009). The WIBS-4 version of the instrument is also capable of being operated in a different threshold and detector amplification mode in order to size larger particles, but this option was not used here. Following initial particle detection and sizing, two optically filtered Xenon flash-lamps are sequentially triggered providing excitation wavelengths centred at $280 \pm 10 \mathrm{~nm}$ and $370 \pm 20 \mathrm{~nm}$ with an impinging energy density ranging from $320-350 \mu \mathrm{J} \mathrm{cm}^{-2}$. In WIBS-3 two spherical mirrors, each subtending 1.33 steradians, each focus part of the fluorescence emission onto one of two photomultiplier tubes (PMTs) that are optically filtered to limit wavelength response to one of two bands that do not overlap the excitation emission, $320-400 \mathrm{~nm}$ and $410-650 \mathrm{~nm}$. In WIBS-4, the fluorescence emission is collected by both mirrors and split into two channels using a dichroic filter at $410 \mathrm{~nm}$ before being measured by two PMTs. This results in greater sensitivity compared to the WIBS-3.

Both PMTs record fluorescence during the $280 \mathrm{~nm}$ excitation phase because no detection bands overlap the excitation band, however only the $410-650 \mathrm{~nm}$ PMT detector is active during the $350 \mathrm{~nm}$ excitation. In subsequent discussions herein the three fluorescent channels will be referred to as FL1 (fluorescence between 300 and $400 \mathrm{~nm}$, following excitation at $280 \mathrm{~nm}$ ), FL2 (fluorescence between 410 and $650 \mathrm{~nm}$, following $280 \mathrm{~nm}$ excitation) and FL3 (fluorescence between 410 and $650 \mathrm{~nm}$, following excitation at $370 \mathrm{~nm}$ ). The autofluorescence arising from the $280 \mathrm{~nm}$ excitation in biological material is influenced heavily by proteins and the bio-molecule tryptophan, whereas fluorescence from $370 \mathrm{~nm}$ excitation is influenced by riboflavin and co-enzyme $\mathrm{NAD}(\mathrm{P}) \mathrm{H}$, (Benson et al., 1979; Billinton and Knight, 2001; Kaye et al., 2005; Li and Humphrey, 1991; Foot et al., 2008). However, fluorescence emission spectra are inherently broad, and interrogating complex microorganisms and micron-sized particles results in a complex mixture of fluorescence emission peaks from many fluorophores that can be difficult to interpret unambiguously (Pöhlker et al., 2013). Further, some types of non-biological material (e.g. certain polycyclic aromatic hydrocarbons and light-absorbing SOA compounds) can fluoresce at wavelengths used by the UV-LIF instruments including WIBS, introducing interference and uncertainty (Gabey et al., 2013; Pöhlker et al., 2013). These interferences, however, can be mitigated in measurement locations that are not heavily impacted by pollution sources and where biofluorescent particles are expected to dominate. The advantage of a multi-wavelength UV-LIF approach compared to single wavelength fluorescence spectrometers was demonstrated by Hill et al. (1999) who found that the fluorescence spectra of bacillus subtilis var niger (BG) vegetative cells are distinguishable from those of fungal spores following a $351 \mathrm{~nm}$ excitation, but not using single wavelength $(266 \mathrm{~nm})$ excitation. The opposite was found for washed and unwashed vegetative cells. Sivaprakasam et al. (2004) e.g. excited particles at $266 \mathrm{~nm}$ and $355 \mathrm{~nm}$ and measured their total fluorescent intensity in wavebands centred at 350, 450 and $550 \mathrm{~nm}$. They concluded that some differentiation between bioaerosol types (although not at the species level) can be possible with multiple excitations. More detailed work suggests a minimum of 8-10 fluorescent wavebands are required to distinguish e.g. between specific spore and bacterial types (e.g. NATO, 2010). Laboratory experiments cited in the above references suggest the WIBS wavelength band resolution would be insufficient to distinguish between either the change in UV fluorescence waveband as a result of atmospheric oxidation of PBAs, desiccation of fungal spores, or due to an increase in size due to water uptake (Santarpia et al., 2012). WIBS therefore represents a compromise, but is still a significant improvement on existing field deployable 
single waveband UV-LIF aerosol spectrometers that have been used in previous studies.

It should be emphasised that the main difference between the WIBS-3 and WIBS-4 instruments is in the optical chamber design and disposition of the detector wavelength bands in each, with WIBS-4 fluorescence detection expected to be more sensitive than WIBS-3. The impact this may have on the fluorescence analysis presented here and how the two instruments should be compared will be mentioned further below but is discussed in greater detail by Robinson et al. (2013).

\section{Data quality control and analysis}

Because the particle collection efficiency of the WIBS drops below $50 \%$ at $\sim 0.8 \mu \mathrm{m}$, we have chosen to integrate number concentrations of particles $>0.8 \mu \mathrm{m}$ rather than apply a correction factor to the concentrations below this size. During standard operation, the xenon flash lamps fire only when triggered by an incoming particle. The background fluorescence levels in both WIBS were routinely measured in each fluorescence channel in the absence of particles (i.e. forced triggering). The WIBS-4 instrument automatically makes 10 such measurements if measured concentrations are lower than 2 counts $\mathrm{s}^{-1}$ for a sustained period of time, on the basis that the coincidence of a forced trigger measurement with a particle in the measurement region is small. These forced trigger data are interpolated over the duration of the experiment to provide a fluorescence baseline for each fluorescence channel, which is subtracted from the single particle fluorescence measurements. It also allows the construction of a fluorescence threshold for each channel, above which a particle is deemed to be significantly fluorescent, defined as the fluorescence baseline plus three standard deviations. Size and fluorescence calibration responses for each instrument was carried out using NIST PSL latex standard particles and "blue" UV-fluorescence particles (Thermo Scientific, USA and PolyScience Inc., USA, respectively), as described by Robinson et al. (2013). The small negative baseline trends calculated for each channel, which can vary between instruments, were also used to correct the fluorescence criteria thresholds for each instrument.

Data collected during the BEACHON-RoMBAS study showed excellent agreement between the WIBS-3 and WIBS-4 fluorescence aerosol concentrations despite the instruments being separated horizontally by $300 \mathrm{~m}$ within the forest (Robinson et al., 2013). The instrument agreement in particle size was also within the laboratory derived sizing accuracies supporting the cluster analysis approach we use to discriminate between different particle types at the two locations (see below). Correlation of total particle concentrations between the WIBS-4 and a co-located optical particle counter (OPC; Grimm Instruments, Model 1.108, Germany) showed good agreement. Concentration values be- low $1000 \mathrm{~L}^{-1}$ are linearly correlated between instruments $\left(N_{\text {WIBS- }}=1.05 \cdot N_{\text {GRIMM }}+3.5, r^{2}=0.77\right)$. The undercounting of WIBS total concentration with respect to the OPC may indicate particle coincidence in the WIBS at higher concentrations. Average concentrations at this site were however low, typically $<50$ to $200 \mathrm{~L}^{-1}$ so in general this was not deemed to be an issue. Concentrations were briefly observed above $1000 \mathrm{~L}^{-1}$ (i.e. during rain events) and therefore we suspect WIBS may underestimate slightly total particle concentrations during these events. The fixed height reference WIBS-3 was operated continuously between 21 July and 8 August 2011, with the exception of brief, occasional lightning-induced power outages.

\section{Analysis and results}

\subsection{Meteorological factors}

Figure 1 is a summary of the meteorological factors that prevailed during the experiment showing the average diurnal cycles in temperature $\left({ }^{\circ} \mathrm{C}\right)$, relative humidity $(\mathrm{RH})(\%)$ and wind speed $\left(\mathrm{m} \mathrm{s}^{-1}\right)$, recorded at the $2 \mathrm{~m}$ elevation alongside the WIBS-3. Median temperatures ranged from nocturnal minima of $9-10{ }^{\circ} \mathrm{C}$ to afternoon maxima of $26^{\circ} \mathrm{C}$. $\mathrm{RH}$ ranged from daytime values of $25 \%$ to night-time values of $86 \%$. Wind speeds were very low beneath the canopy, ranging from $0.6 \mathrm{~m} \mathrm{~s}^{-1}$ during nocturnal periods to $1.1 \mathrm{~m} \mathrm{~s}^{-1}$ during the daytime. Greater variability in $\mathrm{RH}$ and net radiation during the afternoons was the result of periodic thundershowers, caused by cloud cover and increased moisture following rain (see also Schumacher et al., 2013). Most rainfall events occurred during the afternoon.

Figure 2 shows the time series of total particle number concentrations measured by the WIBS-3 $\left(\mathrm{L}^{-1}\right)$ as well as the concentrations of particles $\left(\mathrm{L}^{-1}\right)$ detected in each of the UV fluorescent channels (FL1-3) over the major part of the experiment. Strong diurnal variation in all channels was observed, modulated by boundary layer stability and rainfall. Typical average diurnal total aerosol concentrations, $N_{\mathrm{T}}$, ranged from daytime minima of $50-100 \mathrm{~L}^{-1}$, to nighttime maxima of $200-300 \mathrm{~L}^{-1}$. As described by Huffman et al. (2013), the large excursions in aerosol concentrations, sometimes exceeding $800 \mathrm{~L}^{-1}$, were strongly correlated with rainfall events, which could exceed $40 \mathrm{~mm} \mathrm{~h}^{-1}$ and occurred mainly during the afternoon and evening periods. These large enhancements in concentrations were observed within all the fluorescent channels. Huffman et al. (2013) and Schumacher et al. (2013) each categorised PBA data from the site into three categories with respect to rain ("dry", "during rain", and "after rain"), each with distinct aerosol properties. However, because the boundary between rain events and the high $\mathrm{RH}$ periods that followed is difficult to unambiguously ascertain, we have chosen here to simplify this classification into two categories ("dry" and "wet") for interpretation of 

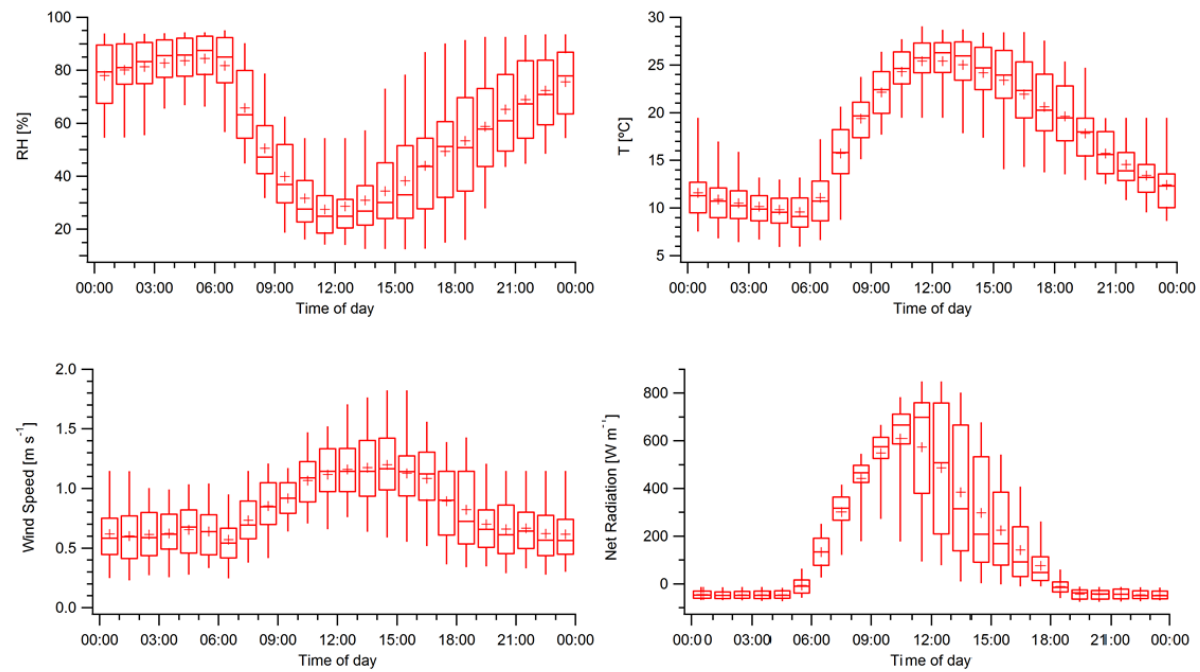

Figure 1. Average diurnal cycles of (a) Relative Humidity, RH (\%), (b) Temperature $\left({ }^{\circ} \mathrm{C}\right)$, and (c) Wind speed (m s $\left.{ }^{-1}\right)(\mathbf{d})$ net radiation $\left(\mathrm{W} \mathrm{m}^{-2}\right)$, all recorded at $2 \mathrm{~m}$ next to the WIBS-3 during the experiment. Data is binned into $1 \mathrm{~h}$ intervals. Time reported as Mountain Standard Time (MST).

the general fluorescent particle behaviour. We define wet periods as the time from when rain-fall was first detected until $6 \mathrm{~h}$ after rain had stopped, and dry periods as all other times. These events will be discussed further below with respect to the rainfall-induced variation in fluorescent cluster analysisderived concentrations and their parameterisation.

\section{Hierarchical agglomerative cluster analysis}

UV-LIF is not capable of identifying biological particles at a biological genus or species level, however, broad identification may be possible by referencing laboratory UVfluorescence behaviour of known particle types in the future. Work to confirm the UV-LIF response by WIBS to many different biological and non-biological particles continues. Previous approaches have used normalised combinatorial ratios of FL1, FL2 and FL3 intensities (e.g. Gabey et al., 2010; Gabey, 2011, and references cited within) where very different UV responses for different generic PBA classes were observed. However, to allow us to interpret the multidimensional single-particle WIBS data sets in a more rigorous statistical manner, and without any a priori particle type assignment, we have used a hierarchical agglomerative cluster analysis technique to statistically segregate physically distinct particle types constrained solely by the instrument diagnostic variable space.

Details of this HA-CA (hierarchical agglomerative cluster analysis) technique, the cluster selection criteria used, how it can be applied to WIBS UV-LIF data sets, and a demonstration of its accuracy and limitations in discriminating a priori particle types can be found in Robinson et al. (2013). They also present an analysis of the differences between the two WIBS instruments used here also using data collected during the BEACHON experiment. They show clearly that a relatively larger number of physically different particle clusters could be identified within the WIBS-4 data set compared to that from the WIBS-3. The improved discrimination power of the WIBS-4, they concluded, was due to its revised chamber design and different optical filters used for the detection wavebands compared to WIBS-3. In summary, for this BEACHON data set we were able to identify six statistically robust particle classes with the WIBS-4 compared to four with the WIBS-3 using the strict selection criteria based on the cluster coefficient of determination and the average root mean square distance between the clusters. The WIBS3 data set tended to conflate some clusters, although the final generic clusters were still internally consistent and conserved between both instruments, as was also clearly demonstrated by Robinson et al. (2013). The four statistically distinct major cluster solutions identified in the WIBS- 3 data set are summarised for a typical period in Table 1 along with those contemporaneously sampled and identified by WIBS-4 (when WIBS-4 was located at the same height as the WIBS3 ). Values are shown with associated variability (standard deviation) of each metric. The low relative variability of the fluorescence signals and $A_{\mathrm{f}}$ reflects that the variability of these values within each cluster is relatively small, whereas the relative variability of particle size within each cluster is larger. This suggests that fluorescence and morphological characteristics are more conserved by a clustered group of particles, while a relatively broader distribution of particles can show the same non-size related characteristics. The cluster solutions will be referred to as clusters $A_{3}-D_{3}$, and $A_{4}-D_{4}$ in subsequent discussions, where the subscript refers to the WIBS model number. Here cluster $A_{3}$ appears to be a conflation of clusters $A_{4,1}$ and $A_{4,2}$. Similarly cluster $B_{3}$ appears 


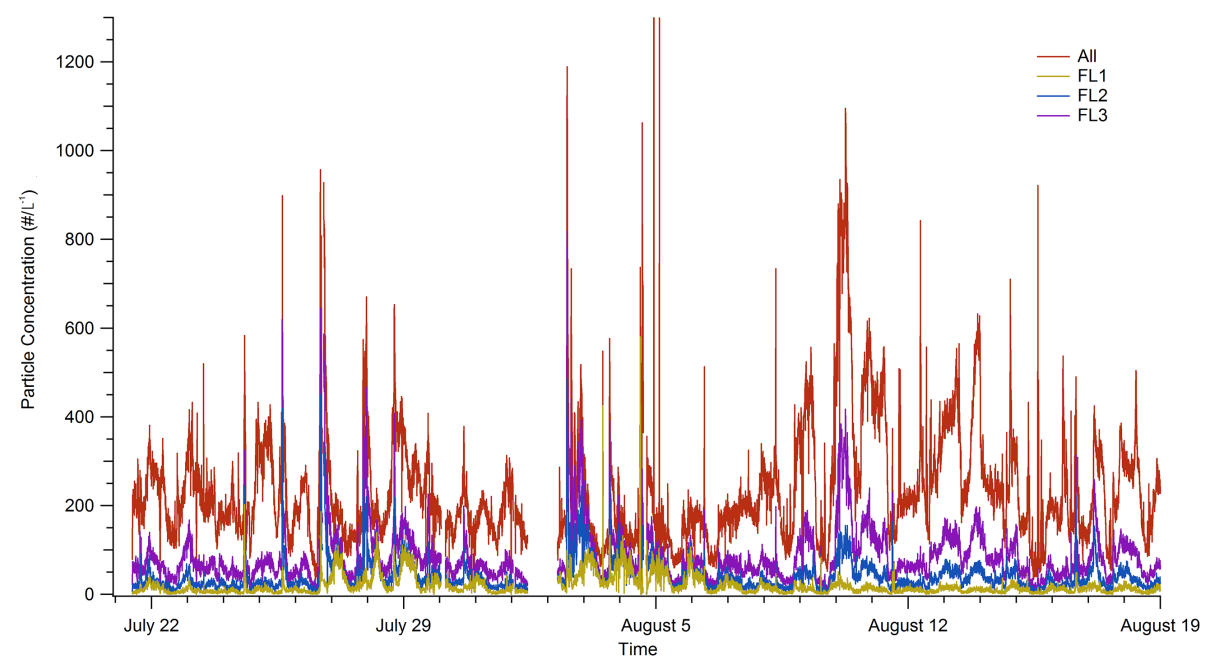

Figure 2. Time series of total particle concentration $\left(\# \mathrm{~L}^{-1}\right)$ recorded by the WIBS-3 at $2 \mathrm{~m}$ during the experiment and concentrations of particles detected in each of the UV-fluorescence channels, FL1-3.

to be a conflation of clusters $B_{4,1}$ and $B_{4,2}$ as described by Robinson et al. (2013). The HA-CA cluster solutions were then used to re-construct quantitative cluster concentration time series using the population-normalised distance simple attribution method. The behaviour of each cluster time series was then examined for its individual response to meteorological factors. A brief description of the clusters follows.

Clusters $A_{3}, A_{4,1}$ and $A_{4,2}$ are abundant, non-fluorescent, small in diameter and have a low asymmetry factor indicating that they are quasi-spherical in nature. We assign these clusters to be representative of the tail end of the ambient aerosol accumulation mode, and as such are assumed to be comprised of several sources (e.g. secondary organic aerosol). These are the only distinctly non-fluorescent clusters retrieved by the analysis.

The remaining clusters each display significant fluorescence in at least one detection channel and are of the order of several microns in particle diameter. They also feature relatively large asymmetry factors, indicative of significantly particle asphericity. As such, we classify these clusters as being representative of classes of fluorescent PBAs, however, a suitable reference library to positively identify them into taxonomic classes does not currently exist. We have identified clusters $B_{3}$ and $B_{4}, 1$ and 2 to be behaviourally consistent with fungal spores, and clusters $C_{3}$ and $C_{4}$ to be behaviourally consistent with bacterial aerosol, which is discussed in detail in later sections.

For the purposes of this analysis we will focus on the four-cluster WIBS-3 solutions, as in the previous work by Robinson et al. (2013), when discussing the surface reference data sets. This is to provide consistency when comparing the two instruments with their different sampling locations in the forest, as well as with data sets previously collected at different forest locations using different WIBS instruments as well as for future reference with improved UV-LIF instruments. When considering the more detailed vertical profile data from WIBS-4, we will refer to the six-cluster solutions as appropriate. Table 1 summarises the typical average concentrations for each of the FL1-3 channels, as well as values for $D_{\mathrm{o}}$ and $A_{\mathrm{f}}$ associated with each of the cluster solutions.

In order to sensibly interpret the cluster time series and their likely behaviour it is prudent to know what PBA types are likely to occur at the site. Several different PBA species were previously observed at this site using fluorescence scanning electron microscope (SEM) and DNA analysis of filter samples performed as part of this project and described in Huffman et al. (2013) and Prenni et al. (2013), though characterisation of PBA classes was not intended to be comprehensive. Examples of identified groups include the following: Bacteria - Proteobacteria, Actinobacteria, Firmicutes, Bacteroidetes, Enterobacteriaceae and Pseudomonadaceae; Fungal spores - Basidiomycota (club fungi), Ascomycota (sac fungi), and smut fungi. We defer to these previous studies and infer what a particular fluorescent PBA cluster may be comprised of based on the knowledge of how these PBA types are known to respond to meteorological parameters. Further investigation of the fluorescent characteristics of PBA classes is recommended to validate cluster assignments.

\subsection{Non-fluorescent particle cluster behaviour}

Cluster $A_{3}$ is comprised of nearly spherical, non-fluorescent particles with mean diameter $1.6 \mu \mathrm{m}$ and dominates the aerosol population. It is consistent with the tail of the expected sub- $2 \mu \mathrm{m}$ non-biological accumulation mode aerosol population measured at this site with other instruments. Inspection of the "dry" periods only, shows that these exhibit typically higher concentrations during the night with a minimum during the day (Fig. 3). Typical median concentrations 
Table 1. WIBS-3 cluster solutions, $A_{3}-D_{3}$, WIBS-4 cluster solutions, $A_{4}-D_{4}$, showing typical average UV FL1-3 channel intensities, average optical diameter, $D_{\mathrm{O}}(\mu \mathrm{m})$, asymmetry factor, $A_{\mathrm{f}}$, and associated standard deviations within each cluster.

\begin{tabular}{lcccccc}
\hline WIBS-3 & $A_{3}$ & & $B_{3}$ & & $C_{3}$ & $D_{3}$ \\
\hline FL1 $(280 \mathrm{~nm})$ & $25 \pm 3.1$ & - & $1725 \pm 6.6$ & - & $87 \pm 1.6$ & $1542 \pm 0.5$ \\
FL2 $(280 \mathrm{~nm})$ & $44 \pm 1.4$ & - & $230 \pm 0.5$ & - & $331 \pm 0.4$ & $1475 \pm 0.2$ \\
FL2 $370(370 \mathrm{~nm})$ & $90 \pm 1.6$ & - & $136 \pm 0.1$ & - & $1224 \pm 0.3$ & $1885 \pm 0.1$ \\
$D_{0}(\mu \mathrm{m})$ & $1.6 \pm 1.6$ & - & $2.9 \pm 1.6$ & - & $3.1 \pm 1.7$ & $4.4 \pm 1.6$ \\
$A_{\mathrm{f}}($ a.u. & $15.9 \pm 1.8$ & - & $21.2 \pm 1.5$ & - & $17.5 \pm 2.2$ & $18.5 \pm 1.5$ \\
$\#$ (relative) & 9670 & - & 456 & - & 243 & 43 \\
\hline WIBS-4 & $\mathrm{A}_{4,1}$ & $\mathrm{~A}_{4,2}$ & $\mathrm{~B}_{4,1}$ & $\mathrm{~B}_{4,2}$ & $\mathrm{C}_{4}$ & $\mathrm{D}_{4}$ \\
\hline FL1 $(280 \mathrm{~nm})$ & $5.0 \pm 3.8$ & $30.0 \pm 2.1$ & $2087 \pm 0.0$ & $1124 \pm 0.6$ & $86 \pm 1.5$ & $2110 \pm 0.0$ \\
FL2 $(280 \mathrm{~nm})$ & $98 \pm 1.4$ & $702 \pm 0.5$ & $1486 \pm 0.3$ & $518 \pm 0.5$ & $1849 \pm 0.2$ & $2055 \pm 0.0$ \\
FL2 370 $(370 \mathrm{~nm})$ & $80 \pm 1.3$ & $620 \pm 0.5$ & $492 \pm 0.6$ & $119 \pm 0.9$ & $1893 \pm 0.1$ & $1822 \pm 0.1$ \\
$D_{0}(\mu \mathrm{m})$ & $1.6 \pm 1.6$ & $2.1 \pm 2.0$ & $3.5 \pm 1.4$ & $2.4 \pm 1.5$ & $2.8 \pm 1.8$ & $4.9 \pm 1.4$ \\
$A_{\mathrm{f}}($ a.u. & $8.6 \pm 2.0$ & $9.5 \pm 2.3$ & $20.6 \pm 1.8$ & $15.6 \pm 1.9$ & $12.3 \pm 3.5$ & $26.8 \pm 1.8$ \\
$\#$ (relative) & 7934 & 384 & 138 & 92 & 91 & 27 \\
\hline Assignment & Non-biological & Non-biological & PBA & PBA & PBA & PBA \\
\hline
\end{tabular}

ranged from $N \sim 250 \mathrm{~L}^{-1}$ at night with a minimum of $150 \mathrm{~L}^{-1}$ around midday. The largest variations in concentration occurred between midnight and early morning with hourly peak concentrations (5 to 95th percentile) occasionally exceeding $N \sim 700 \mathrm{~L}^{-1}$. This behaviour is broadly consistent with submicron organic aerosol (OA) observations during the same time period (Ortega et al., 2014) and is consistent with stable nocturnal boundary layer enhancement of accumulation mode particulate concentrations, facilitated by light nocturnal winds, which is then followed by a reduction in concentrations due to turbulent dispersion and mixing during the daytime. During "wet" conditions the picture is less consistent, with concentrations being modulated both by rain scavenging and mechanically generated emissions arising from kinetic energy input from impacting raindrops during rain events. However, the cluster still shows a minimum during the middle of the day and, as a result, the average range in peak concentrations is significantly reduced over the period from midnight to early morning compared to the same period under dry conditions.

\subsection{Fluorescent particle cluster behaviour}

The diurnal variations of the "bio"-fluorescent particle clusters are considered next. For both wet and dry cases the number concentrations of cluster $B_{3}$ display a strong diurnal signature with maxima occurring at night, and minima around midday (Fig. 4). During the wet periods there is a large nocturnal concentration enhancement which remains consistently high throughout the night and into the early morning, with median concentrations around $N \sim 20-30 \mathrm{~L}^{-1}$, but with significantly larger variations than the dry period with average peak concentrations exceeding $N \sim 60 \mathrm{~L}^{-1}$. The greater night-time concentrations of cluster $B_{3}$ during wet periods are consistent with previous suggestions that PBAs released during and after rain remain aloft for many hours (Huffman et al., 2013). Fluorescent particles on average exhibited significantly larger $A_{\mathrm{f}}$ values (more aspherical) than the smaller non-fluorescent particles. This may be due to a limitation arising as a result of the minimum size resolution of the instrument and the inherent uncertainties associated with the Mie-solution, relating particle scattering cross section to particle size in this size range. However the analysis by Robinson et al. (2013), suggests this observed change in $A_{\mathrm{f}}$ is still statistically significant when compared to the WIBS response to spherical calibration particles.

Similar to cluster $B_{3}$, the dry condition maximum in number concentration of cluster $C_{3}$ occurred around midnight, with a minimum at noon, Fig. 5. This may suggest a sensitivity to UV radiation. Cazorla et al. (2003) showed the colony forming units of $P$. syringae to be significantly reduced after $4 \mathrm{~h}$ exposure to UV radiation. As this cluster is likely to be bacterial in nature (as discussed later) this may explain the minimum. Concentrations ranged from $N \sim 5-$ $10 \mathrm{~L}^{-1}$, and were significantly higher than observed for cluster $B_{3}$. The largest variation in concentrations during dry periods also occurred during midnight to early morning periods with peak concentrations exceeding $N \sim 30 \mathrm{~L}^{-1}$. During wet periods this diurnal behaviour exhibits significantly increased concentrations and larger variability during the late afternoon and evening periods (peaks ranging from $N \sim 40$ $60 \mathrm{~L}^{-1}$ typically) when most rain events occurred.

The diurnal cycle of cluster $D_{3}$ is shown in Fig. 6. These particles were the largest in physical size, with mean cluster diameter of $D_{\mathrm{o}}=4.4 \pm 1.6 \mu \mathrm{m}$. Both the dry and wet periods showed a strong diurnal variation displaying a typical nocturnal maxima and a minimum during the day with concentrations ranging from $N<1$ to $10 \mathrm{~L}^{-1}$, however the 

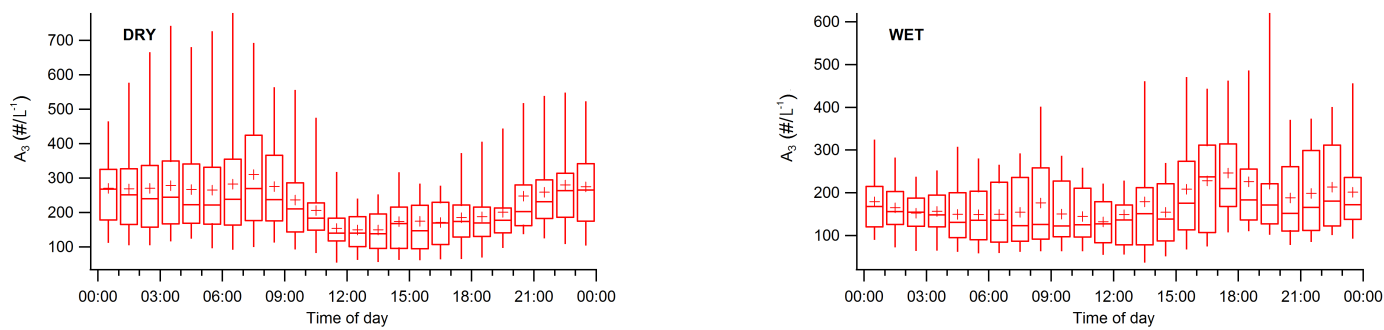

Figure 3. The average diurnal variation of cluster $A_{3}$ (non-fluorescent particles) during dry (top) and wet (bottom) periods. Whiskers represent the 5 th and 95 th percentiles; the boxes, inter quartile ranges. The central line represents the median, and the mean is shown by the cross symbol.
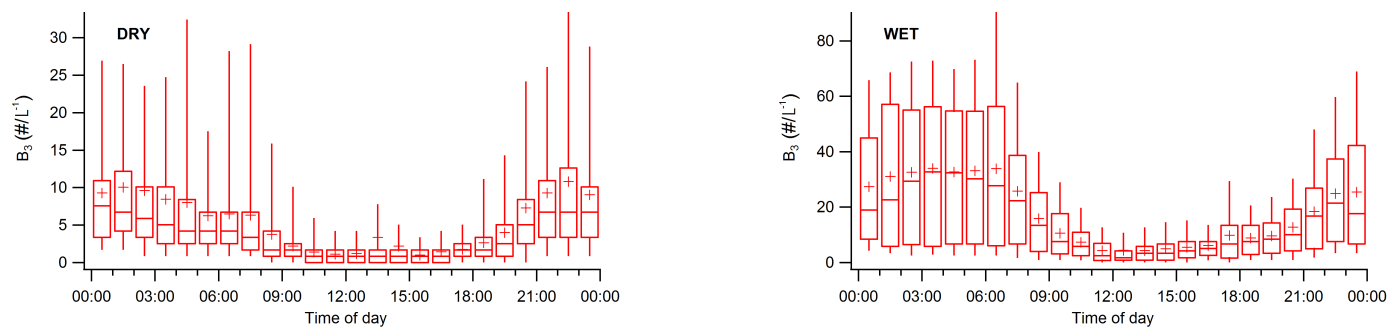

Figure 4. As Fig. 3 but showing cluster $B_{3}$ during dry periods (top), and wet periods (bottom).

concentration of particles in $D_{3}$ were higher during wet periods.

The relative contribution of fluorescent particles $\left(B_{3}+\right.$ $C_{3}+D_{3}$ ) to the total (fluorescent + non-fluorescent) aerosol population was $5.8 \%$ during the dry periods and $15.2 \%$ ( $\sim 3 \times$ larger) during wet periods, consistent with previous observations from the study of dramatic increases in bioparticle concentrations during rain (Huffman et al., 2013; Prenni et al., 2013). A breakdown of the individual percentage cluster contributions to the total fluorescent particle population for both the dry and wet periods was investigated (Fig. 7). The relative contribution of $B_{3}$ and $C_{3}$ showed contrasting trends between dry and wet periods, with $B_{3}$ accounting for $37 \%$ in dry and $54 \%$ in wet periods, respectively, and $C_{3}$ accounting for $49 \%$ in dry and $35 \%$ in wet periods, respectively. The relative proportion of $D_{3}$ to total fluorescent particles was relatively unchanged ( $14 \%$ to $11 \%$ ), despite a significant increase in total fluorescent particle concentration during rain.

\subsection{General behaviour of fluorescent PBAs with height in the forest canopy}

The average concentration of each fluorescent cluster is dependent on many factors. Figure 8 shows the response of each cluster, segregated by height, by wetness, and by time of day. Day and night period definitions used here were determined using the observed diurnal net radiation profiles. In all cases it was observed that the number concentration of particles in fluorescent clusters was the greatest at night (darker colours of green and brown), with further enhance- ment during wet periods (hatched). In addition, the in-canopy (green) concentrations were larger than those observed at ground level (brown), an important point. This suggests that the largest source of these emitted bioaerosol is tree foliage and trunk surfaces rather than from sources at the ground. This contrasts with limited studies in tropical rain forests using microscopic assay techniques, e.g. Gilbert and Reynolds (2005) who found greater spore densities in the understory of a tropical forest than in the canopy. During the day the greatest number concentrations of fluorescent particles were generally observed during wet periods, with the exception of cluster $C_{4}$, which suffers a slight reduction from wet to dry during the day. This behaviour may be attributed to the site predominantly being comprised of ponderosa pine $(60 \%$ coverage, leaf area index $=1.9)$ with minimal undergrowth (DiGangi et al., 2011), as opposed to tropical forests with lush undergrowth. Similarly the non-fluorescent aerosol concentration is the greatest at night, however in contrast to trends in fluorescent particles, concentrations of non-fluorescent particles were significantly enhanced during dry periods (solid bars) compared with wet periods (hatched bars), by factors of $\sim 50-90 \%$. This suggests that there are significant losses of non-fluorescent particles due to wet deposition, with the greatest losses observed within the canopy.

The extent of the vertical diurnal variation in particle concentration and wet enhancement can further be seen in Fig. 9 . The concentration of cluster $B_{4,1}$ shows enhancement in the canopy $(10-20 \mathrm{~m})$ at night during wet periods with even stronger enhancement at ground level. In contrast, cluster $C_{4}$ shows enhancement in concentration within the mid-to-lower 

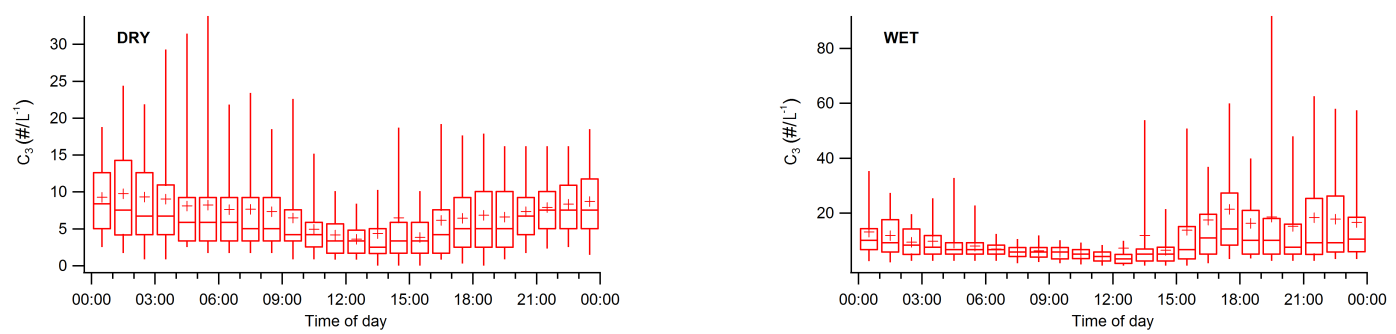

Figure 5. As Fig. 3 but showing cluster $C_{3}$ during dry periods (top), and wet periods (bottom).
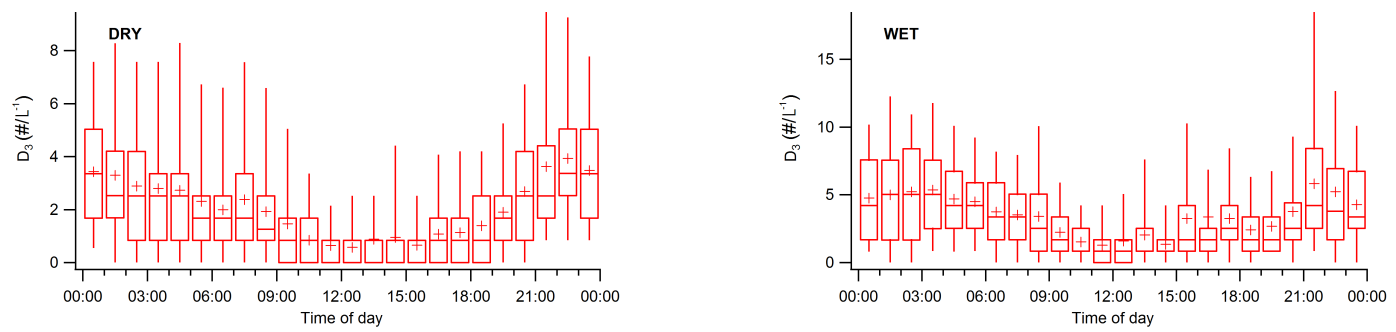

Figure 6. As Fig. 3 but showing cluster $D_{3}$ during dry periods (top), and wet periods (bottom).
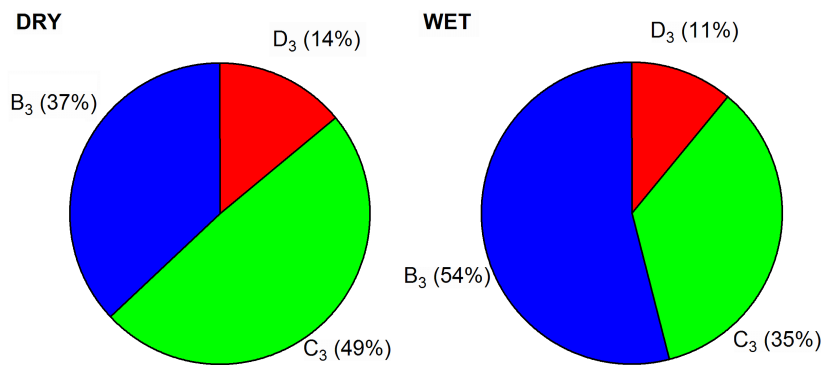

Figure 7. WIBS-3 fluorescent cluster fractions $B_{3}, C_{3}$ and $D_{3}$ observed during dry (left) and wet (right) periods.

canopy (7.5-15 m) during wet periods between 16:00 and 00:00 LT.

\section{Response of fluorescent particle clusters to meteorological parameters}

\subsection{Relative humidity}

Concentration of fluorescent particles shows a positive correlation with $\mathrm{RH}$ when averaged over the full measurement period (Fig. 10). The relationship can be expressed linearly in $\log -\log$ space for both the dry and wet case. It is necessary to use two fits for the wet case as there is a significant enhancement in number concentration at $\mathrm{RH} \geq 70 \%$ :

$\log _{10}\left(\mathrm{Fl}_{\text {tot }}(\right.$ dry $\left.)\right)=0.57885 \cdot \log _{10}(\mathrm{RH})+0.91028$
$\log _{10}\left(\mathrm{Fl}_{\text {tot }}(\right.$ wet $\left.)\right)=\left\{\begin{array}{l}0.42756 \cdot \log _{10}(\mathrm{RH})+1.0962, \mathrm{RH}<70 \% \\ 1.8174 \cdot \log _{10}(\mathrm{RH})-1.4548, \mathrm{RH} \geq 70 \%\end{array}\right.$
Without simultaneous multi-height measurements it is not possible to unambiguously assign the source of these particles, i.e. whether they result from raindrop splashing from the top layer in the canopy, or are being carried down in the rain itself, or both. Figure 11 shows the response of the WIBS-3 resolved fluorescent clusters, $B_{3}-D_{3}$, to changes in relative humidity $(\mathrm{RH})$ for dry periods. The right panel shows the ratio of the cluster $D_{3}$ concentration to $\mathrm{Fl}_{\text {tot }}$ where it can be seen that these account for $2-3 \%$ of the total fluorescent number concentration for $\mathrm{RH}$ over the range 0 $40 \%$. At higher RH values this increases slightly to a median of 3-4\%. Generally speaking, concentrations of cluster $D_{3}$ showed only a small response during "dry" periods (as defined here) to the diurnal change in RH. There is a slight suppression in the observed ratio at the highest $\mathrm{RH}$, possibly due to dew formation trapping the particles as reviewed by Jones and Harrison (2004) and also observed at the MEFO site by Schumacher et al. (2013). The middle panel shows the ratio of cluster $C_{3}$ to $\mathrm{Fl}_{\text {tot }}$, where $C_{3}$ comprises approximately $7 \%$ of all fluorescent particles and exhibits a sharp decrease to a few percent at the highest observed RH. The left panel shows the ratio of cluster $B_{3}$ to $\mathrm{Fl}_{\text {tot }}$ which shows a much greater response to changes in $\mathrm{RH}$ than the other biological clusters. For RH values up to $\sim 35 \%, B_{3}$ accounts for 3-5\% of all the fluorescent material detected. For RH $>35 \%$ this increases to $6-12 \%$ with a further increase to $20 \%$ at the highest observed humidity. The relationship between the ratio of the dry $B_{3}$ cluster concentration to the total fluorescent concentration and RH can be expressed with two linear fits 


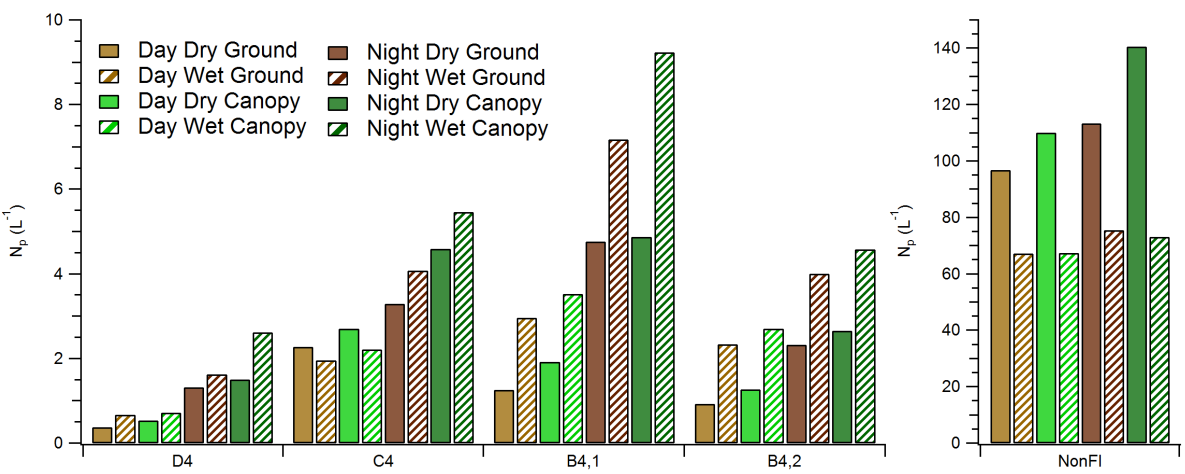

Figure 8. Bar chart of WIBS4 average cluster and non-fluorescent particle concentration. Data has been averaged for all permutations of day (light) and night (dark); wet (diagonal lines) and dry (solid); ground (browns) and canopy (greens). Ground: $z<5 \mathrm{~m}$, canopy: $18<z<21 \mathrm{~m}$. Day: 05:00-19:00, night: 19:00-05:00.

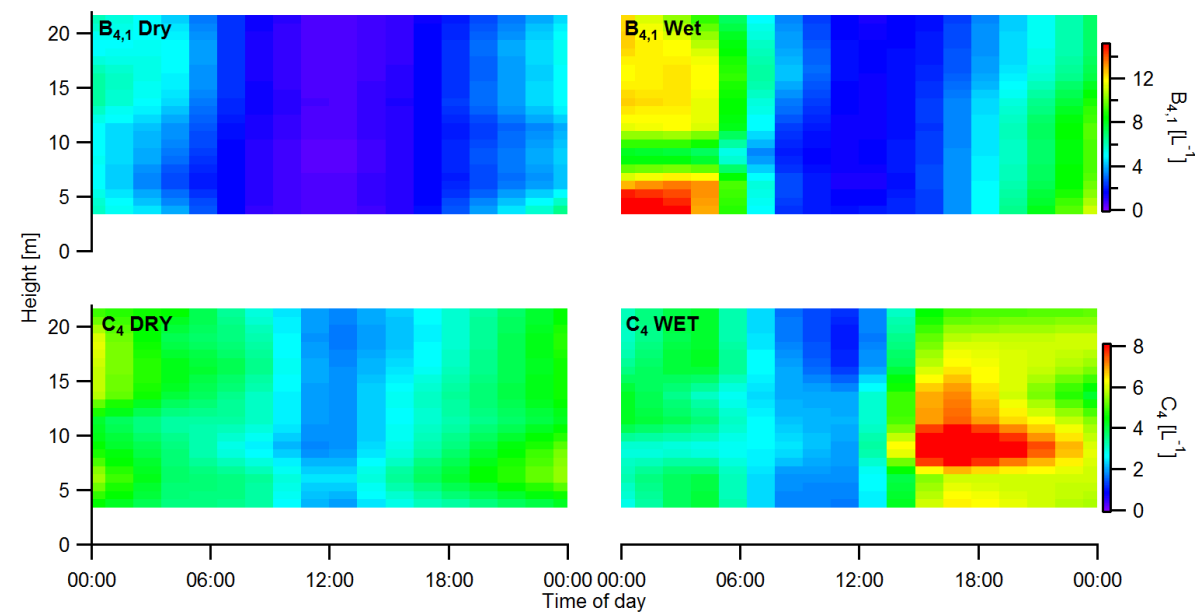

Figure 9. Diurnal concentration profile of cluster $B_{4,1}$ (top row) $C_{4}$ (bottom row) for dry (left column) and wet (right column) periods.

in $\log -\log$ space:

$\log _{10}\left(B_{3} / \mathrm{Fl}_{\text {tot }}(\mathrm{dry})\right)=\left\{\begin{array}{l}0.55191 \cdot \log _{10}(\mathrm{RH})-2.0847, \mathrm{RH}<90 \% \\ 18.169 \cdot \log _{10}(\mathrm{RH})-36.415, \mathrm{RH} \geq 90 \%\end{array}\right.$

Figure 12 shows the RH response of each cluster under wet conditions. Cluster $D_{3}$ is not significantly more sensitive to changes in RH compared to the "dry" condition data set (right panel), with between 3-6\% of the total fluorescent material being assigned to this cluster across the range of observed RH, a slight increase over the dry case. Cluster $C_{3}$ again displays very little variation in their contribution to the fraction of fluorescent material, making up approximately $10 \%$ of the total fluorescent aerosol observed. This is slightly more than in the dry case. Similarly to the dry case, there is a reduction in their fractional contribution at the very highest humidity, which is interesting. Cluster $B_{3}$ displays a strong response to increase in RH particularly under wet conditions (Fig. 12, left panel). For RH $<40 \%, B_{3}$ contributes up to $10 \%$ of the fluorescent material. For RHs of between 40 to $90 \%$, these aerosols make up between 10 to
$25 \%$ of the fluorescent particles. This increases to $60 \%$ for the very highest RHs observed. The relationship between the ratio of the wet $B_{3}$ cluster concentration to the total fluorescent concentration and RH can be expressed with two linear fits in $\log -\log$ space:

$\log _{10}\left(B_{3} / \mathrm{Fl}_{\text {tot }}(\right.$ wet $\left.)\right)=\left\{\begin{array}{l}0.87882 \cdot \log _{10}(\mathrm{RH})-2.3981, \mathrm{RH}<88.8 \% \\ 8.2562 \cdot \log _{10}(\mathrm{RH})-16.701, \mathrm{RH} \geq 88.8 \%\end{array}\right.$

Figure 13 shows the response of $B_{3}$ number concentration to $\mathrm{RH}$ for a typical dry day, starting from the midday minimum where the effect of a minimum threshold RH can clearly be seen; there is a sharp increase in number concentration at 20:00 when RH sharply increases above $\sim 60 \%$. $B_{3}$ particle number concentration decreases again dramatically when RH decreases below approximately $40 \%$ (08:30). Relative humidity has been demonstrated to be related to the emission of fungal spores by several studies with Hirst (1953) first noting the direct relationship between Basidiomycota fungal spore release and RH. Later, Pringle et al. (2005) and Elbert et al. (2007) demonstrated that Basidiomycota 
actively eject spores and that the mechanism was controlled directly by response to ambient relative humidity. Gabey et al. (2010) also suggested rapid release of fungal spores when RH thresholds were reached in a tropical forest in Malaysia. Similarly, multiple recent publications have suggested that diurnal patterns of fluorescent particle concentrations were regulated active emission of fungal spores due to the night time enhancement of RH (e.g. Huffman et al., 2013; Pöschl et al., 2010; Schumacher et al., 2013; Toprak and Schnaiter, 2013). Basidiomycota spores have also been identified at the MEFO site during measurements collected in parallel with the study reported here (Huffman et al., 2013; Prenni et al., 2013). As such we suggest that cluster $B_{3}$ is likely representative of fungal spores.

\subsection{Effects of rainfall events on PBA concentrations}

Rainfall can significantly alter the concentration of PBAs within plant canopies by means of mechanical agitation and through enhancement of RH. Enhancement, by splash dispersal of spores and bacteria was first demonstrated over a century ago by Miquel (1883) and many following studies showed various other PBA types to be dispersed by rainfall (Faulwetter, 1917; Stepanov, 1935; Glynne, 1953; Hirst, 1953). Gregory et al. (1959) suggested that primary splash of a rain drop of $0.5>D_{\mathrm{p}}>5 \mathrm{~mm}$ could disperse thousands of spore carrying droplets and secondary splashes may also contribute further. Hirst (1953) suggested that increased moisture associated with rainfall may also provide stimulation for active discharge mechanism in some fungal species. Figure 14 shows the response of the particle size distributions and concentration to rainfall of the three fluorescent WIBS-3 clusters for several different rain events of different intensities. Cluster $C_{3}$ shows a strong instantaneous response to rainfall over three separate rain events with peak concentrations occurring just after peak rainfall which then undergo an exponential decay. Cluster $D_{3}$ also shows a positive response to rainfall but to a much lesser extent than $C_{3}$. Cluster $B_{3}$ shows an increase due to rain but the peak rain-induced concentrations are much less than those seen during its diurnal maximum. Suppression in number concentration is observed just after a rainfall event when compared to the dry diurnal response. The response of $B_{3}$ is therefore largely driven by diurnal variation in temperature and $\mathrm{RH}$ which are modulated by rainfall.

To clarify the influence of rain rate on cluster $C_{3}$ the peak rain rate at the onset of rain was plotted against the peak $C_{3}$ cluster concentration. From observation the peak in the $C_{3}$ cluster concentration occurs slightly after the peak in rainfall rate. In this case the observed delay is 5 min (one time bin), although this is limited by the counting statistics of the WIBS instrument and should be taken as an upper limit. A strong positive relationship between the peak concentration and peak rain rate was observed (Fig. 15, middle panel), which can be expressed with two linear fits in log-linear space (Eq. 5). Caution must be applied when extrapolating this parameterisation for rain rates below $0.1 \mathrm{~mm} \mathrm{~h}^{-1}$ and in excess of $10 \mathrm{~mm} \mathrm{~h}^{-1}$ due to the paucity of data here. At much higher rain rates losses from wet deposition scavenging may become increasingly significant.

$C_{3}=\left\{\begin{array}{l}3.0858 \cdot \log _{10}\left(\mathrm{RR}_{\text {peak }}\right)+27.369, \mathrm{RR}_{\text {peak }}<0.81 \mathrm{~mm} \mathrm{~h}^{-1} \\ 50.442 \cdot \log _{10}\left(\mathrm{RR}_{\text {peak }}\right)+31.6691, \mathrm{RR}_{\text {peak }} \geq 0.81 \mathrm{~mm} \mathrm{~h}^{-1}\end{array}\right.$

The behaviour of cluster $C_{3}$ during rain events is consistent with the results of studies by Constantinidou (1990) and Lindemann and Upper (1985) who observed that the concentration of bacterial aerosol measured directly above crops increased by up to a factor of 25 during rain events. As such, we suggest that cluster $C_{3}$ is representative of aerosol which are either bacterial aggregates or aerosol containing or associated with bacteria.

Cluster $D_{3}$ (Fig. 15, right panel) also shows a weak positive correlation between number concentration and rain rate. The response of cluster $B_{3}$ is less straight forward and is likely a result of several different mechanisms; increasing rainfall rate up to approximately $1 \mathrm{~mm} \mathrm{~h}^{-1}$ has the effect of increasing the cluster concentration. Further increase in rainfall rate suppresses the number concentration, which we speculate is due to scavenging and wet deposition.

\subsection{Summary of fluorescent cluster behaviour}

Clusters $B_{3}$ and $C_{3}$ display behaviour consistent with previous measurements of fungal spores and bacteria, respectively. Cluster $B_{3}$ has been shown to exhibit a strong diurnal response, with maximum concentrations occurring at night when RH is enhanced (Fig. 4). This cluster was found to respond strongly to increases in $\mathrm{RH}$, with the cluster accounting for $60 \%$ of the observed fluorescent material at high RH under wet conditions (Fig. 12). This behaviour is consistent with that of emission of fungal spores as described earlier (Hirst, 1953; Pringle et al., 2005; Elbert et al., 2007; Jones and Harrison, 2004), as such we suggest that cluster $B_{3}$ is representative of fungal spores. The concentration of cluster $C_{3}$ is strongly increased by rainfall, with enhancements of the order of 10-20 being observed with respect to the dry concentration (Fig. 14). This behaviour is consistent with that of bacterial aggregates or aerosol containing or associated with bacteria (Constantinidou, 1990; Lindemann and Upper, 1985), so we suggest that cluster $C_{3}$ is representative of bacterial aerosol. The origin of cluster $D_{3}$ is unknown at this time, however, we believe it is likely to be PBAs given its highly fluorescent nature, large size and asphericity.

\section{Comparison with other studies at the MEFO site}

Huffman et al. (2013); Prenni et al. (2013) and Tobo et al. (2013) each recently showed that the number concentration of IN correlated linearly with the number concentration of 

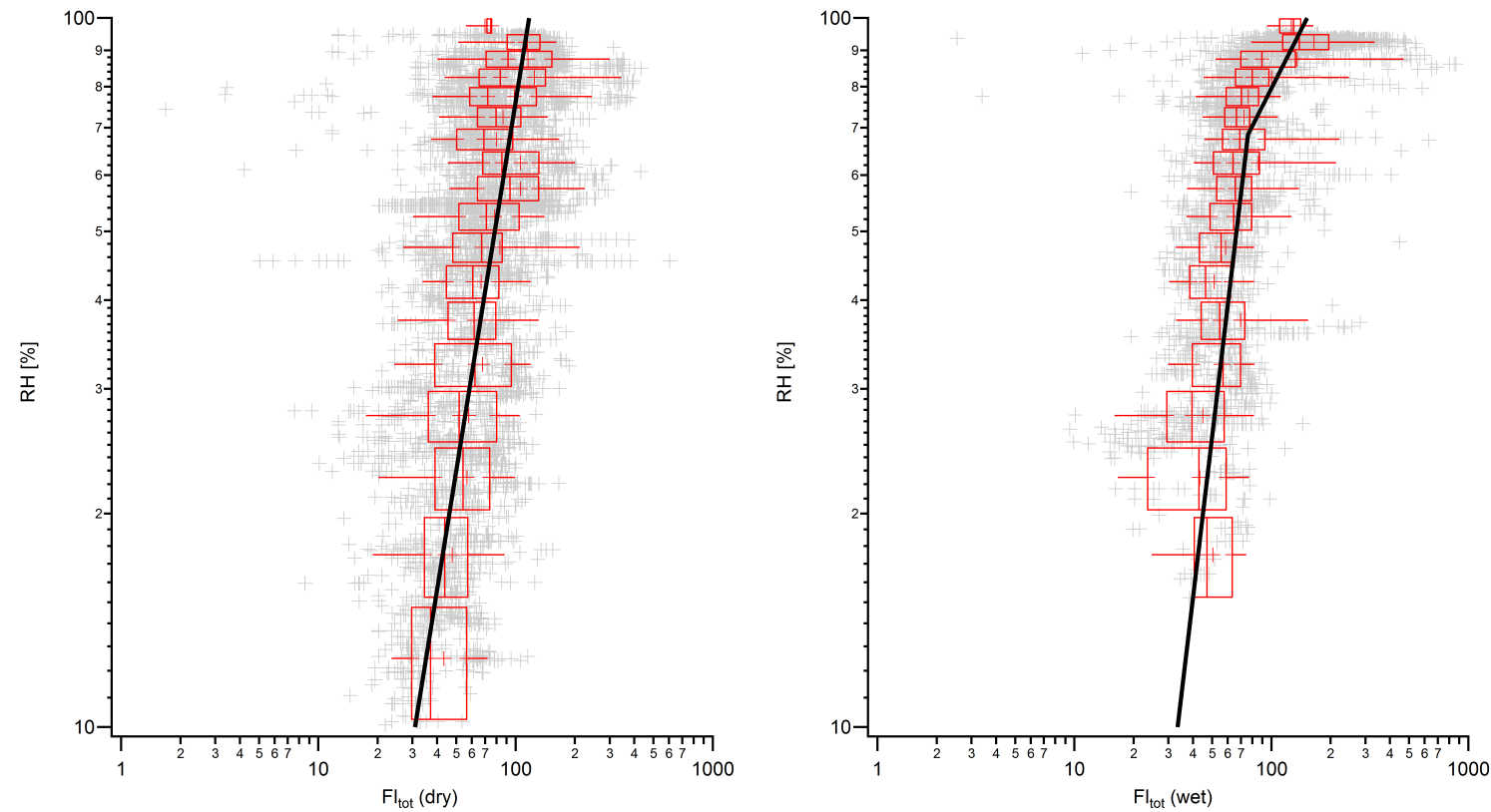

Figure 10. RH Response of total fluorescent particle number concentration, $\mathrm{Fl}_{\mathrm{tot}}$, for dry (left) and wet (right) periods with linear fits in $\log -\log$ space added (see Eqs. 1-2.) Norm of residuals: $\mathrm{Fl}_{\text {tot }}($ dry $)=0.36 ; \mathrm{Fl}_{\text {tot }}($ wet, $\mathrm{RH}<70 \%),=0.17 ; \mathrm{Fl}_{\text {tot }}($ wet, $\mathrm{RH} \geq 70 \%)=0.20$.
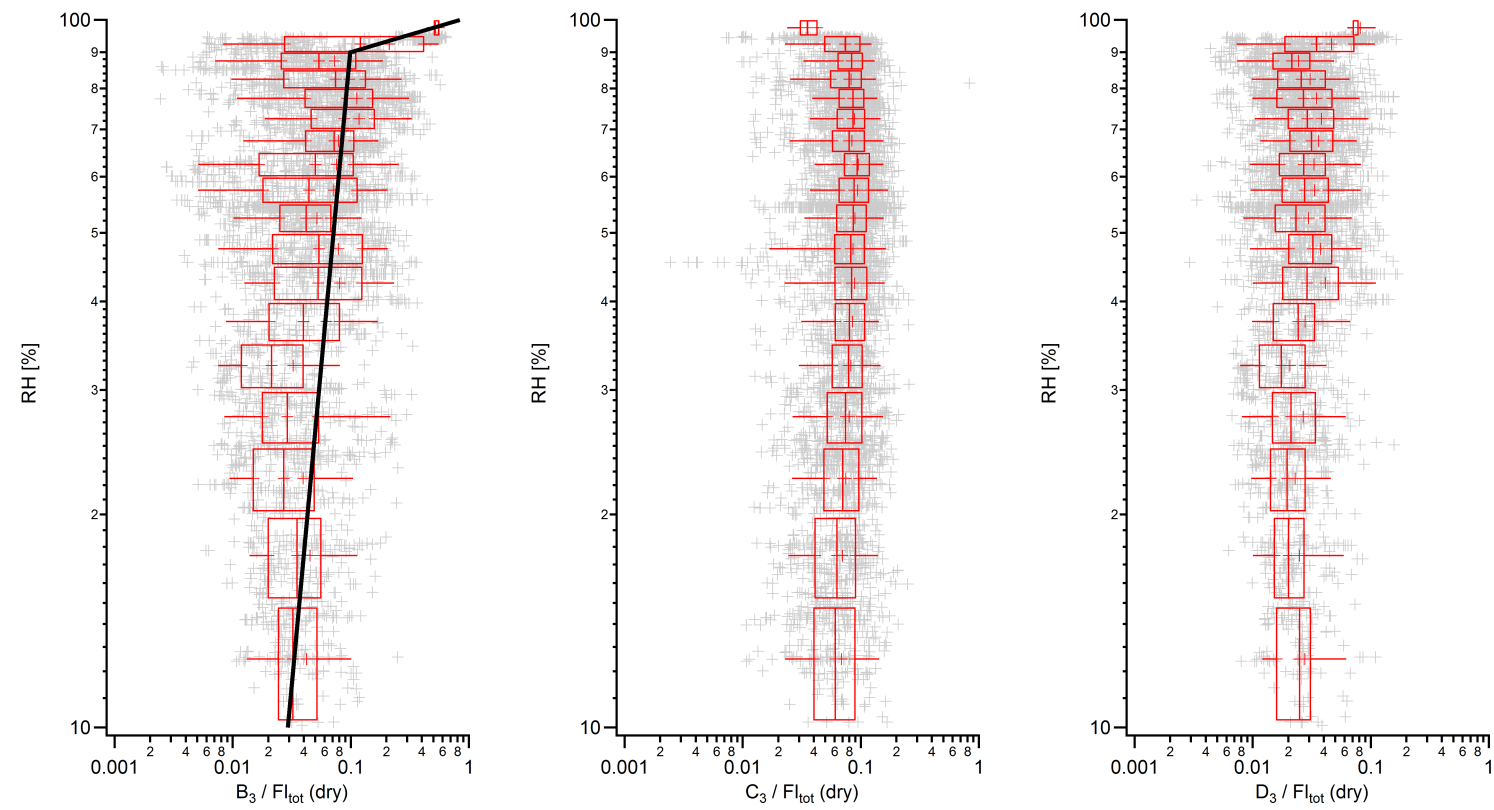

Figure 11. Ratio of fluorescent cluster number concentration to total fluorescent particle concentration $\left(\mathrm{Fl}_{\text {tot }}\right)$ as a function of relative humidity $(\mathrm{RH} \%)$ in dry conditions. Left to right; cluster $B_{3}$; cluster $C_{3}$; cluster $D_{3}$; whiskers represent the 5 th and 95 th percentiles; boxes show inter-quartile range with the central marker being the median and the mean is shown with a cross marker. A linear fit in log-log space has been added to $B_{3}$ (see Eq. 3). Norm of residuals: $B_{3} / \mathrm{Fl}_{\text {tot }}($ dry, $\mathrm{RH}<90 \%)=0.37 ; B_{3} / \mathrm{Fl}_{\text {tot }}(\mathrm{dry}, \mathrm{RH} \geq 90 \%)=0.02$.

fluorescent particles during rain events at the site. Total IN concentrations were measured using a continuous flow diffusion chamber (CFDC) ice nucleus counter. The CFDC was operated at $-25^{\circ} \mathrm{C}$ over an $\mathrm{RH}$ range of $103-106 \%$ making it suitable for the detection of condensation/immersion freezing nuclei (Sullivan et al., 2010). Ice nuclei concentrations were typically an order of magnitude higher in wet periods than during dry periods, with IN concentrations of the order of several tens per litre with a maximum observed concentration of approximately $180 \mathrm{~L}^{-1}$ (Huffman et al., 2013; 

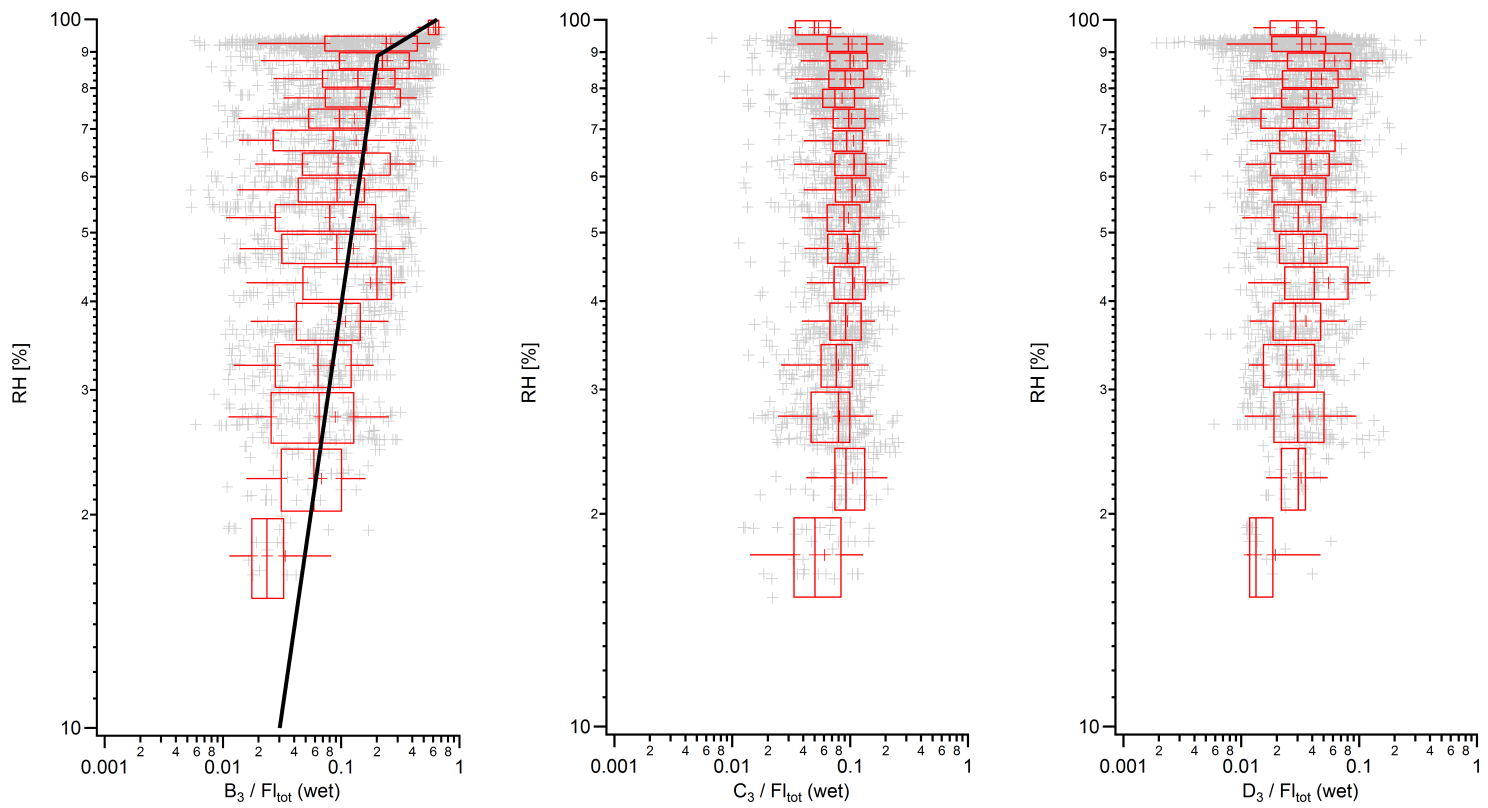

Figure 12. As for Fig. 11 but for wet conditions. A linear fit in $\log -\log$ space has been added to $B_{3}$ (see Eq. 4). Norm of residuals: $B_{3} / \mathrm{Fl}_{\text {tot }}($ wet, $\mathrm{RH}<88.8 \%)=0.34 ; B_{3} / \mathrm{Fl}_{\text {tot }}($ wet, $\mathrm{RH} \geq 88.8 \%)=0.14$.

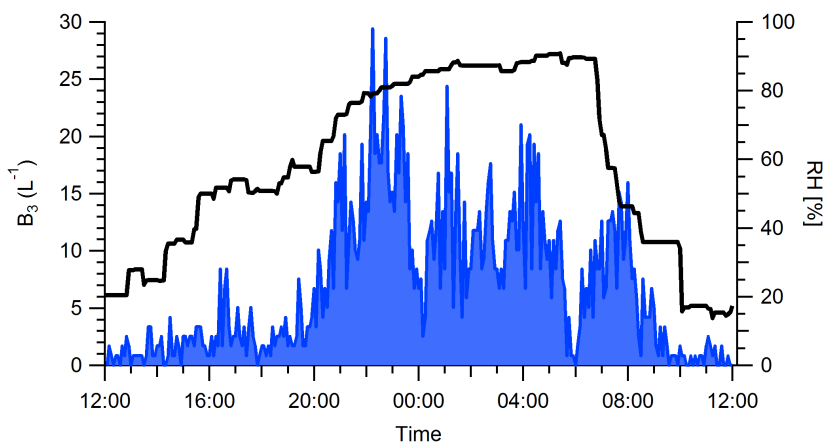

Figure 13. RH (right) and associated $B_{3}$ concentration (left) for a dry $24 \mathrm{~h}$ period starting 12:00 27 July 2013.

Prenni et al., 2013; Tobo et al., 2013). These authors suggested, therefore, that a significant fraction of these IN may have been biological in origin, which we now discuss.

Several bacteria have been identified as acting as efficient IN at temperatures warmer than $-10^{\circ} \mathrm{C}$. However, even in species with known ice activity, often relatively few individuals within a population (e.g. $<1 \%$ ) activate to form ice crystals via condensation or immersion freezing (Möhler et al., 2008b). During dry periods the concentration of $C_{3}$ is approximately $10 \mathrm{~L}^{-1}$. Möhler et al. (2008b) demonstrated Pseudomonas syringae to have a maximum ice active fraction of 0.005. Assuming all particles from Cluster $C_{3}$ contained exactly one $P$. syringae organism, this would suggest a maximum IN yield of $0.025 \mathrm{~L}^{-1}$, which is approximately two orders of magnitude less than the IN concentrations ob- served during dry periods. During rainfall events the concentration of $B_{3}$ spans several 10 's $\mathrm{L}^{-1}$ to up to $200 \mathrm{~L}^{-1}$, yielding a maximum IN concentration of $1 \mathrm{~L}^{-1}$, which is again approximately two orders of magnitude less than the observed IN concentration. If cluster $B_{3}$ is representative of bacterial aerosol at the site it is unlikely that they contribute significantly to the observed IN unless they exhibit considerably greater ice active fractions than the $P$. syringae measured previously.

Currently the ice activity of fungal spores is unclear. Pummer et al. (2013) recently reported that common fungal spore species do not exhibit significantly ice activity and so they suggested that the contribution of fungal spores to observed IN concentration is negligible. In contrast, other groups have reported fungal species with very efficient ice nucleating behaviour at high temperatures (e.g. Morris et al., 2013; Haga et al., 2013; Huffman et al., 2013). Cluster $B_{3}$ shows a strong diurnal response, which is seemingly linked to the enhancement of RH at night. No diurnal trend in IN concentrations was reported at the site during dry periods (Huffman et al., 2013; Prenni et al., 2013) which suggests that this cluster, which we believe to be representative of fungal spores, is not likely to be significantly ice active. The relationship between IN and fluorescent particles observed at this site and reported previously does not necessarily mean that the IN are biological or fluorescent in nature, though the high degree of correlation is suggestive. However, the IN observed during rain and dry periods could alternatively have been non-biological in origin. The fluorescent properties of the detected IN were 


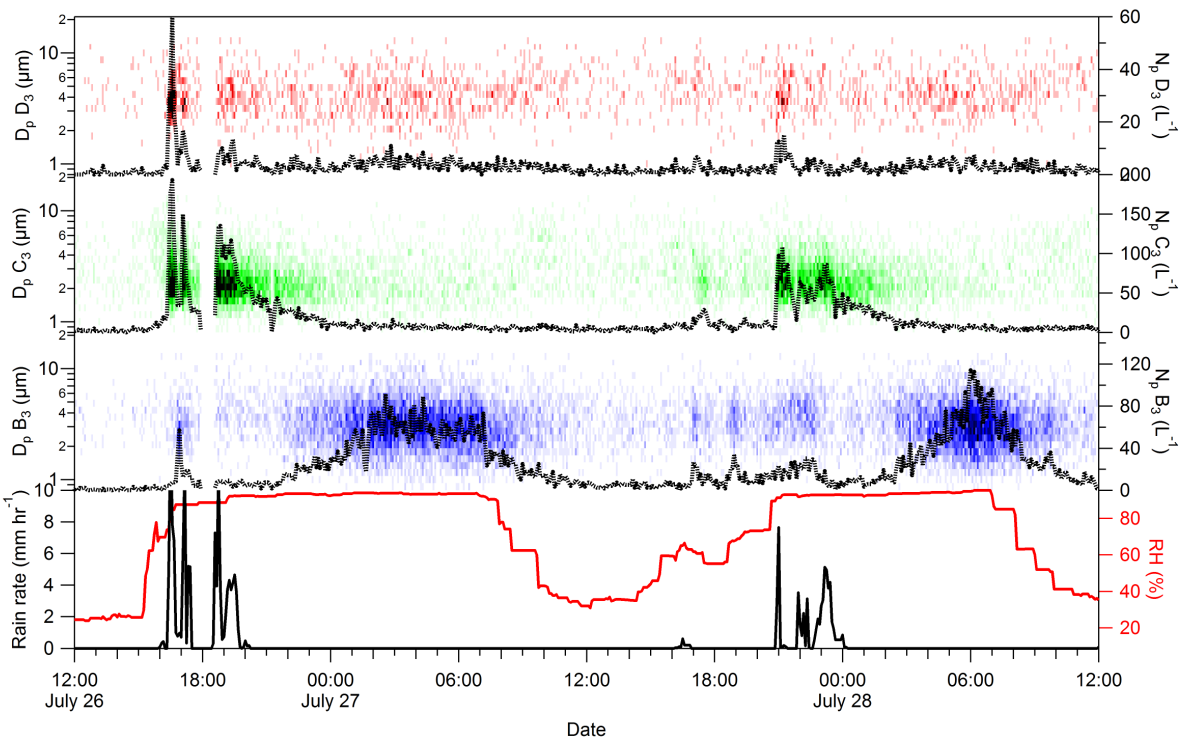

Figure 14. Response of cluster size distribution and number concentration $\left(\# \mathrm{~L}^{-1}\right)$ to rainfall and relative humidity. (a) Time series of $D_{3}$ size distribution (diameter in $\mu \mathrm{m}$ ) (left) and cluster number concentration (right); (b) same as (a) but for $C_{3}$; (c) same as (a) but for $B_{3}$; (d) rain rate $\left(\mathrm{mm} \mathrm{h}^{-1}\right)$ (left) and $\mathrm{RH}(\%)$ (right). Rainfall data provided by A. Turnipseed at NCAR.

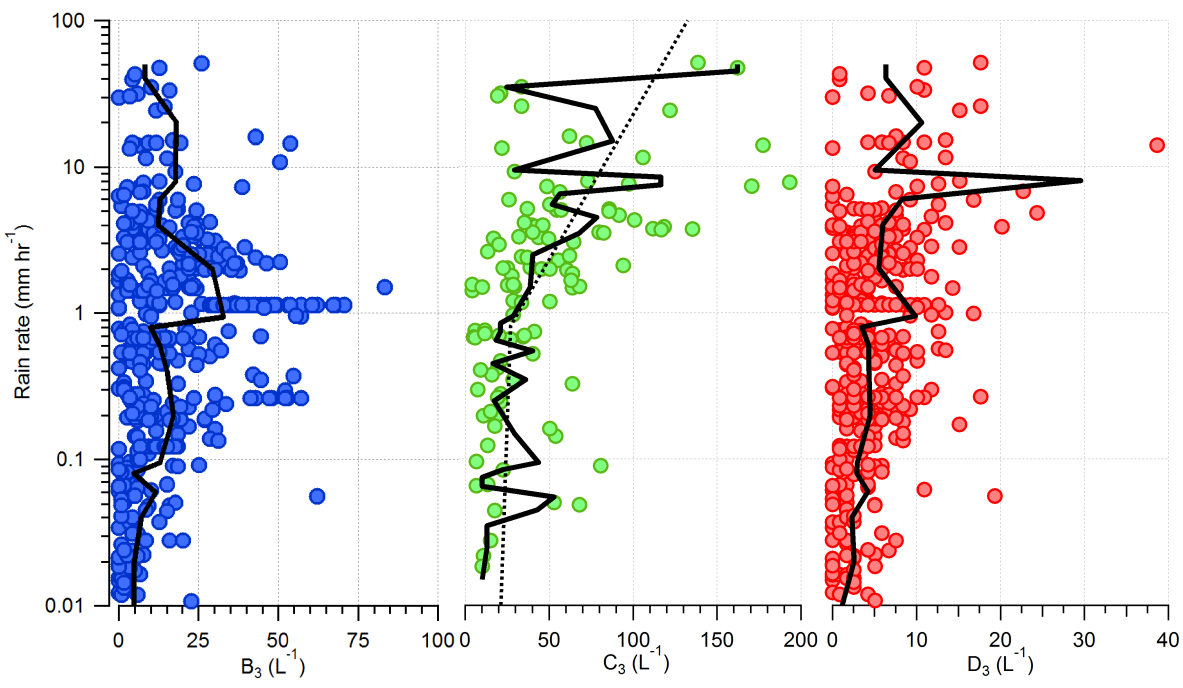

Figure 15. Scatter of fluorescent cluster concentration vs. rain rate. Black line is mean value. Dashed line is linear fit in log-linear space (see text) as described in Eq. (5). The instantaneous response to rain is shown for clusters $B_{3}$ and $D_{3}$ (left and right panels). A small time offset of $5 \mathrm{~min}$ (one time bin) is introduced for cluster $C_{3}$ (middle panel, see text), additionally for clarity only peak concentrations are shown for this cluster. Norm of residuals: $C_{3}\left(\mathrm{RR}<0.81 \mathrm{~mm} \mathrm{~h}^{-1}\right)=54 ; C_{3}\left(\mathrm{RR} \geq 0.81 \mathrm{~mm} \mathrm{~h}^{-1}\right)=82$.

not measured directly and thus remain yet unidentified in specific.

\section{Canopy bioaerosol particle fluxes}

Bioaerosol fluxes were estimated using the methodology presented by Lindemann et al. (1982) by using the WIBS-4 cluster concentration gradient and vertical wind speed measured with several sonic anemometers mounted on the flux tower.
In order to use this approach we must make two assumptions. Firstly the instantaneous concentration gradient is well represented at the two heights of interest. In order to remove any influence from diurnal variation and to minimise the effect of instantaneous events due to rapid changes in the meteorological conditions we calculate the gradient flux using the $3 \mathrm{~min}$ descending profiles. Secondly we assume that the technique is valid within a forest canopy. We have relaxed the usual constraints that would negate this assumption by citing the 

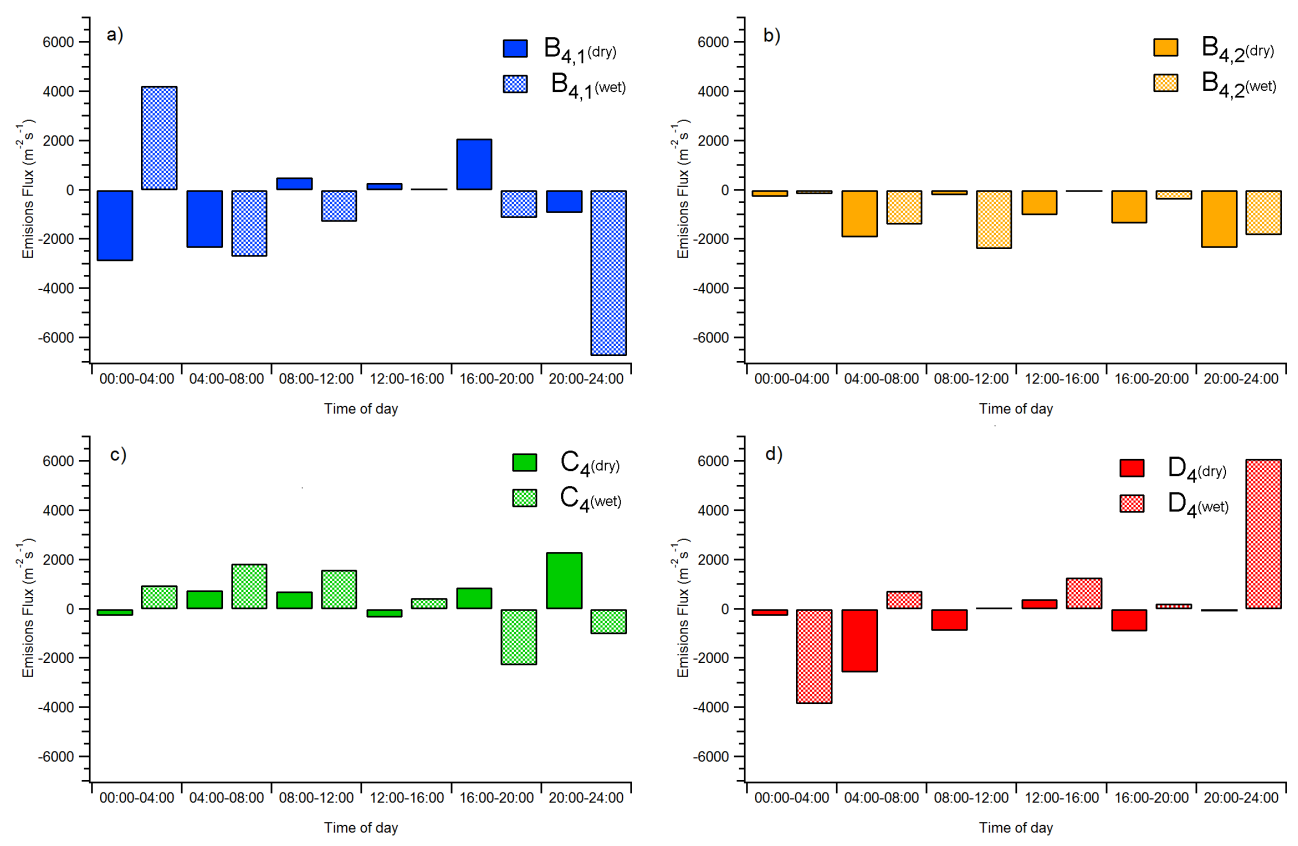

Figure 16. Diurnal PBA Emissions flux $\left(\# \mathrm{~m}^{-2} \mathrm{~s}^{-1}\right.$ ) from the canopy during dry (solid) and wet (chequered) periods for the following: (a) $B_{4,1} ;$ (b) $B_{4,2}$ (c) $C_{4} ;$ (d) $D_{4}$.

relatively sparse canopy in this study with low LAI in order to compare the relative changes between particle types with height. The fluxes estimated here therefore are subject to significant uncertainties and will be the subject of a further more detailed analysis paper.

Figure 16 shows the diurnal cluster emissions flux from the top of the canopy independently for wet and dry periods. It can generally be seen that most of the PBA-like clusters are deposited to the canopy and so are unlikely to be emitted in significant numbers into the boundary layer above. The clear exception is cluster $C_{4}$ which is generally emitted throughout the day, suggesting that the tentatively suggested bacteria are emitted from the canopy into the boundary layer with relatively high efficiency. The influence of rain on the emission flux of cluster $C_{4}$ is not straight forward to interpret. Other notable emissions arise during wet periods during the night from clusters $B_{4,1}$ and $D_{4}$, suggesting that the tentatively suggested fungal spores are more strongly emitted on wet nights due to enhancements in RH. This general behaviour is consistent with previous studies of fungal spore emission (e.g. Hirst, 1953; Toprak and Schnaiter, 2013) and the response of cluster $C_{3}$ at ground level.

\section{Summary and conclusions}

Hierarchical agglomerative cluster analysis was applied to two contemporaneous sets of WIBS measurements; one at ground level of the forest and the other mounted on a vertically profiling platform. The analysis yielded consistent clus- ter types between the two instruments with clusters characteristic of the tail of the accumulation mode and different primary biological aerosols. In each case similar trends and values were observed between each instrument.

Clusters representative of PBAs all showed a common diurnal trend with minimum concentration occurring at midday and with number concentration enhanced during wet periods. Cluster B showed the greatest enhancement under these conditions. The cluster of non-fluorescent particles also showed a diurnal trend similar to the other clusters, however, scavenging by rain suppressed these number concentrations when compared to dry conditions.

At the forest floor cluster $C_{3}$ (behaviourally consistent with bacteria) dominated the PBA number fraction (49\%) during dry periods. In wet periods the $B_{3}$ cluster (behaviourally consistent with fungal spores) was the major fraction $(54 \%)$. The PBA number concentration however was less at the ground than was found in the canopy where the leaf area index is higher, suggesting the canopy is the main source of these PBA, at least at this location, which is in contrast to tropical rain-forests, although such measurements are limited. There are significant differences in the vertical distributions of the different clusters, however.

The PBA number concentration is greater during wet periods than dry periods with the exception of cluster $C_{4}$ which was less numerous during wet periods at ground level, however, the concentration is enhanced within the canopy during wet periods, again suggesting that the leaf area index is a significant metric for the source of these aerosols as the LAI is much lower at the ground where the undergrowth at 
the site was minimal. This is consistent with the suggestion that the cluster represents bacteria found on plant surfaces. The highest PBA cluster concentrations are observed within the canopy during wet periods and at night where the RH is maximised resulting in peak $B_{4}$ concentrations which likely due do active fungal spore ejection.

As observed in previous studies fluorescent particle number concentration is positively correlated with RH. The response can be parameterised for dry and wet periods at this location by linear regressions in $\log -\log$ space. Of the resolved clusters only $B_{3}$ responds significantly to diurnal changes in RH, suggesting that this cluster is representative of fungal spores. During dry periods at the maximum observed RH, these constitute approximately $20 \%$ of the fluorescent material. In wet periods this is increased to approximately $60 \%$. The other clusters display little response to RH, resulting in them contributing a near constant and minor fraction to the total fluorescent material observed at the site as a function of RH. We acknowledge that the presented parameterisations are likely to only be representative of emissions at the site studied. We recommend that further studies are performed at other sites to inform improved parameterisations.

Rainfall causes direct enhancement in all PBA concentrations with cluster $C_{3}$ responding the strongest. This behaviour is consistent with bacterial concentrations above crops during rain events (Constantinidou, 1990; Lindemann and Upper, 1985) so we suggest that cluster $C_{3}$ is representative of bacterial aerosol. The log of the peak rainfall rate was found to correlate linearly with peak $C_{3}$ number concentration, lending to a simple parameterisation of the response.

Huffman et al. (2013) showed that there was a strong correlation between fluorescent particle number concentration and independently measured IN concentrations during rain events in this experiment. Analysis of the WIBS PBA clusters revealed that it was unlikely that bacteria, at least within the detection capabilities of the UV LIF spectrometers deployed here, contributed significantly to the observed IN concentration due to its low ice active fraction as demonstrated by Möhler et al. (2008b). It is possible that submicron contributions to this particle type are however being under-sampled by WIBS. The evidence for ice nucleating efficacy of fungal spores is conflicting (Pummer et al., 2013; Morris et al., 2013; Haga et al., 2013; Huffman et al., 2013). No diurnal trend in IN concentration was reported and the concentrations of cluster $B_{3}$ during rain events were less than the maximum observed IN concentrations, suggesting that they were not significantly ice active based on the measured IN total concentrations at this location.

In conclusion, the majority of PBAs in terms of number concentration at this forest location appear to be bacterial in nature during dry periods and associated with plant surfaces, with fungal spores dominating in the wet. These would therefore represent the available majority of bio-aerosols that can potentially be transported to higher levels in the atmosphere.
This is also consistent with recent aircraft observations of micro-biome populations, DeLeon-Rodriguez et al. (2013) which suggest plant surface derived bacteria dominate in this high atmosphere region as a result of storm generated uplift.

Acknowledgements. The authors wish express our gratitude to the USFS, NCAR, and in particular R. Oakes, A. Guenther, and J. Smith for providing invaluable logistical support and access to the Manitou Experimental Forest field site. We would also like to acknowledge A. Turnipseed for providing meteorological data without which much of this analysis could not be performed. We would also like to thank C. Robinson at Manchester University for invaluable discussions on fungal spore behaviour. J. A. Huffman acknowledges internal faculty support from the University of Denver. The BEACHON-RoMBAS campaign is partially supported by an ETBC grant to NCAR, the University of Colorado, Colorado State University, and Penn State University (NSF ATM-0919189). Finally we wish to acknowledge and thank D. A. Day and J. L. Jimenez of the University of Colorado for organising the field site logistics and experiment.

Edited by: A. Laaksonen

\section{References}

Barnett, T. P., Pierce, D. W., Hidalgo, H. G., Bonfils, C., Santer, B. D., Das, T., Bala, G., Wood, A. W., Nozawa, T., Mirin, A. A., Cayan, D. R., and Dettinger, M. D.: Humaninduced changes in the hydrology of the western United States, Science, 319, 1080-1083, doi:10.1126/science.1152538, 2008.

Benson, R., Meyer, R., Zaruba, M., and KcKhann, G.: NoCellular autofluorescence - is it due to flavins?, J. Histochem. Cytochem., 27, 44-48, 1979.

Billinton, N. and Knight, A. W.: Seeing the wood through the trees: a review of techniques for distinguishing green fluorescent protein from endogenous autofluorescence, Anal. Biochem., 291, 175-197, doi:10.1006/abio.2000.5006, 2001.

Cazorla, F. M., Arrebola, E., Abad C., Codina, J. C., PérezGarcía, A., and De Vicente, A.: Epiphytic Fitness of Pseudomonas syringae pv. syringae on Mango Trees is Increased by 62-Kb Plasmids. Pseudomonas syringae and related pathogens, 79-88, doi:10.1007/978-94-017-0133-4_8, 2003

Christner, B. C., Morris, C. E., Foreman, C. M., Cai, R., and Sands, D. C.: Ubiquity of biological ice nucleators in snowfall, Science, 319, 1214, doi:10.1126/science.1149757, 2008.

Constantinidou, H. A.: Atmospheric dispersal of ice nucleationactive bacteria: the role of rain, Phytopathology, 80, 934, doi:10.1094/Phyto-80-934, 1990.

Crawford, I., Bower, K. N., Choularton, T. W., Dearden, C., Crosier, J., Westbrook, C., Capes, G., Coe, H., Connolly, P. J., Dorsey, J. R., Gallagher, M. W., Williams, P., Trembath, J., Cui, Z., and Blyth, A.: Ice formation and development in aged, wintertime cumulus over the UK: observations and modelling, Atmos. Chem. Phys., 12, 4963-4985, doi:10.5194/acp-12-49632012, 2012.

Cziczo, D. J., Froyd, K. D., Hoose, C., Jensen, E. J., Diao, M., Zondlo, M. A., Smith, J. B., Twohy, C. H., and Murphy, D. M.: Clarifying the dominant sources and 
mechanisms of cirrus cloud formation, Science, 340, 1320-1324, doi:10.1126/science.1234145, 2013.

DeLeon-Rodriguez, N., Lathem, T. L., Rodriguez-R, L. M., Barazesh, J. M., Anderson, B. E., Beyersdorf, A. J., Ziemba, L. D., Bergin, M., Nenes, A., and Konstantinidis, K. T.: Microbiome of the upper troposphere: species composition and prevalence, effects of tropical storms, and atmospheric implications, P. Natl. Acad. Sci. USA, 110, 2575-2580, doi:10.1073/pnas.1212089110, 2013.

DeMott, P. J., Prenni, A. J., Liu, X., Kreidenweis, S. M., Petters, M. D., Twohy, C. H., Richardson, M. S., Eidhammer, T., and Rogers, D. C.: Predicting global atmospheric ice nuclei distributions and their impacts on climate, P. Natl. Acad. Sci. USA, 107, 11217-11222, doi:10.1073/pnas.0910818107, 2010.

Després, V. R., Huffman, J. A., Burrows, S. M., Hoose, C., Safatov, A. S., Buryak, G., Fröhlich-Nowoisky, J., Elbert, W., Andreae, M. O., Pöschl, U., Jaenicke, R., Alex Huffman, J., Burrows, S. M., Hoose, C., Safatov, A. S., Buryak, G., Fröhlich-Nowoisky, J., Elbert, W., Andreae, M. O., Pöschl, U., and Jaenicke, R.: Primary biological aerosol particles in the atmosphere: a review, Tellus B, 64, 15598, doi:10.3402/tellusb.v64i0.15598, 2012.

Diehl, K., Quick, C., Matthias-Maser, S., Mitra, S. K., and Jaenicke, R.: The ice nucleating ability of pollen: Part I: Laboratory studies in deposition and condensation freezing modes, Atmos. Res., 58, 75-87, 2001.

Diehl, K., Matthias-Maser, S., Jaenicke, R., and Mitra, S. K.: The ice nucleating ability of pollen: Part I I. Laboratory studies in immersion and contact freezing modes, Atmos. Res., 61, 125133 ,

2002.

DiGangi, J. P., Boyle, E. S., Karl, T., Harley, P., Turnipseed, A., Kim, S., Cantrell, C., Maudlin III, R. L., Zheng, W., Flocke, F., Hall, S. R., Ullmann, K., Nakashima, Y., Paul, J. B., Wolfe, G. M., Desai, A. R., Kajii, Y., Guenther, A., and Keutsch, F. N.: First direct measurements of formaldehyde flux via eddy covariance: implications for missing in-canopy formaldehyde sources, Atmos. Chem. Phys., 11, 10565-10578, doi:10.5194/acp-11-10565-2011, 2011.

Elbert, W., Taylor, P. E., Andreae, M. O., and Pöschl, U.: Contribution of fungi to primary biogenic aerosols in the atmosphere: wet and dry discharged spores, carbohydrates, and inorganic ions, Atmos. Chem. Phys., 7, 4569-4588, doi:10.5194/acp-7-4569-2007, 2007.

Faulwetter, R. C.: Wind-blown rain, a factor in disease dissemination, J. Agric. Res., 639-648, 1917.

Foot, V. E., Kaye, P. H., Stanley, W. R., Barrington, S. J., Gallagher, M., and Gabey, A.: Low-cost real-time multiparameter bio-aerosol sensors, P. Soc. Photo-Opt. Ins., 71160I-1-71160I12, doi:10.1117/12.800226, 2008.

Forster, P., Ramaswamy, V., Artaxo, P., Berntsen, T., Betts, R., Fahey, D., Haywood, J., Lean, J., Lowe, D., Myhre, G., Nganga, J., Prinn, R., Raga, G., Schulz, M., and Van Dorland, R.: Changes in atmospheric constituents and in radiative forcing, in: Climate Change 2007: The Physical Science Basis. Contribution of Working Group I to the Fourth Assessment Report of the Intergovernmental Panel on Climate Change, Cambridge University Press, Cambridge, UK, 2007.
Fröhlich-Nowoisky, J., Burrows, S. M., Xie, Z., Engling, G., Solomon, P. A., Fraser, M. P., Mayol-Bracero, O. L., Artaxo, P., Begerow, D., Conrad, R., Andreae, M. O., Després, V. R., and Pöschl, U.: Biogeography in the air: fungal diversity over land and oceans, Biogeosciences, 9, 1125-1136, doi:10.5194/bg-91125-2012, 2012.

Gabey, A. M.: Laboratory and field characterisation of fluorescent and primary biological aerosol particles, Ph.D. thesis, University of Manchester, Manchester, UK, 2011.

Gabey, A. M., Gallagher, M. W., Whitehead, J., Dorsey, J. R., Kaye, P. H., and Stanley, W. R.: Measurements and comparison of primary biological aerosol above and below a tropical forest canopy using a dual channel fluorescence spectrometer, Atmos. Chem. Phys., 10, 4453-4466, doi:10.5194/acp-10-44532010, 2010.

Gabey, A. M., Vaitilingom, M., Freney, E., Boulon, J., Sellegri, K., Gallagher, M. W., Crawford, I. P., Robinson, N. H., Stanley, W. R., and Kaye, P. H.: Observations of fluorescent and biological aerosol at a high-altitude site in central France, Atmos. Chem. Phys., 13, 7415-7428, doi:10.5194/acp-13-74152013, 2013.

Gange, A. C., Gange, E. G., Mohammad, A. B., and Boddy, L.: Host shifts in fungi caused by climate change?, Fungal Ecol., 4, 184-190, doi:10.1016/j.funeco.2010.09.004, 2011.

Gilbert, G. S. and Reynolds, D. R.: Nocturnal fungi: airborne spores in the canopy and understory of a tropical rain forest, Biotropica, 37, 462-464, doi:10.1111/j.1744-7429.2005.00061.x, 2005.

Glynne, M. D.: Wheat yield and soil-borne diseases, Ann. Appl. Biol., 40, 221-224, doi:10.1111/j.1744-7348.1953.tb02382.x, 1953.

Gregory, P. H., Guthrie, E. J., and Bunce, M. E.: Experiments on splash dispersal of fungus spores, J. Gen. Microbiol., 20, 328 354, doi:10.1099/00221287-20-2-328, 1959.

Haga, D. I., Iannone, R., Wheeler, M. J., Mason, R., Polishchuk, E. A., Fetch, T., van der Kamp, B. J., McKendry, I. G., and Bertram, A. K.: Ice nucleation properties of rust and bunt fungal spores and their transport to high altitudes, where they can cause heterogeneous freezing, J. Geophys. Res.-Atmos., 118, 7260-7272, doi:10.1002/jgrd.50556, 2013.

Heald, C. L. and Spracklen, D. V.: Atmospheric budget of primary biological aerosol particles from fungal spores, Geophys. Res. Lett., 36, L09806, doi:10.1029/2009GL037493, 2009.

Hill, S. C., Pinnick, R. G., Niles, S., Pan, Y.-L., Holler, S. Chang, R. K., Bottiger, J., Chen, B. T., Orr, C.-S., and Feather, G.: Real-time measurement of fluorescence spectra from single airborne biological particles, Field Anal. Chem. Tech., 3, 221-239, doi:10.1002/(SICI)1520-6521(1999)3:4/5<221::AIDFACT2>3.0.CO;2-7, 1999.

Hirst, J.: Changes in atmospheric spore content: diurnal periodicity and the effects of weather, T. Brit. Mycol. Soc., 36, 375-393, doi:10.1016/S0007-1536(53)80034-3, 1953.

Hoose, C., Kristjánsson, J. E., and Burrows, S. M.: How important is biological ice nucleation in clouds on a global scale?, Environ. Res. Lett., 5, 024009, doi:10.1088/1748-9326/5/2/024009, 2010.

Huffman, J. A., Prenni, A. J., DeMott, P. J., Pöhlker, C., Mason, R. H., Robinson, N. H., Fröhlich-Nowoisky, J., Tobo, Y., Després, V. R., Garcia, E., Gochis, D. J., Harris, E., MüllerGermann, I., Ruzene, C., Schmer, B., Sinha, B., Day, D. A., Andreae, M. O., Jimenez, J. L., Gallagher, M., Kreidenweis, S. M., 
Bertram, A. K., and Pöschl, U.: High concentrations of biological aerosol particles and ice nuclei during and after rain, Atmos. Chem. Phys., 13, 6151-6164, doi:10.5194/acp-13-61512013, 2013.

Hummel, M., Hoose, C., Gallagher, M., Healy, D. A., Huffman, J. A., O'Connor, D., Pöschl, U., Pöhlker, C., Robinson, N. H., Schnaiter, M., Sodeau, J. R., Toprak, E., and Vogel, H.: Regionalscale simulations of fungal spore aerosols using an emission parameterization adapted to local measurements of fluorescent biological aerosol particles, Atmos. Chem. Phys. Discuss., 14, 9903-9950, doi:10.5194/acpd-14-9903-2014, 2014.

Jacobson, M. Z. and Streets, D. G.: Influence of future anthropogenic emissions on climate, natural emissions, and air quality, J. Geophys. Res., 114, D08118, doi:10.1029/2008JD011476, 2009.

Jones, A. M. and Harrison, R. M.: The effects of meteorological factors on atmospheric bioaerosol concentrations - a review, Sci. Total Environ., 326, 151-180, doi:10.1016/j.scitotenv.2003.11.021, 2004.

Jung, J. H., Ho Lee, C., Eun Lee, J., Hyun Lee, J., Soo Kim, S., and Lee, B. U.: Design and characterization of a fungal bioaerosol generator using multi-orifice air jets and a rotating substrate, J. Aerosol Sci., 40, 72-80, doi:10.1016/j.jaerosci.2008.09.002, 2009.

Kauserud, H. V., Heegaard, E., Semenov, M. A., Boddy, L., Halvorsen, R., Stige, L. C., Sparks, T. H., Gange, A. C., and Stenseth, N. C.: Climate change and spring-fruiting fungi, Proc. Biol. Sci./Royal Soc., 277, 1169-1177, doi:10.1098/rspb.2009.1537, 2010.

Kaye, P. H., Stanley, W. R., Hirst, E., Foot, E. V., Baxter, K. L., and Barrington, S. J.: Single particle multichannel bio-aerosol fluorescence sensor, Opt. Express, 13, 3583, doi:10.1364/OPEX.13.003583, 2005.

Kim, S., Karl, T., Guenther, A., Tyndall, G., Orlando, J., Harley, P., Rasmussen, R., and Apel, E.: Emissions and ambient distributions of Biogenic Volatile Organic Compounds (BVOC) in a ponderosa pine ecosystem: interpretation of PTR-MS mass spectra, Atmos. Chem. Phys., 10, 1759-1771, doi:10.5194/acp-10-17592010, 2010.

Levin, E. J. T., Prenni, A. J., Petters, M. D., Kreidenweis, S. M., Sullivan, R. C., Atwood, S. A., Ortega, J., DeMott, P. J., and Smith, J. N.: An annual cycle of size-resolved aerosol hygroscopicity at a forested site in Colorado, J. Geophys. Res., 117, D06201, doi:10.1029/2011JD016854, 2012.

Li, J. K. and Humphrey, A. E.: Use of fluorometry for monitoring and control of a bioreactor, Biotechnol. Bioeng., 37, 1043-1049, doi:10.1002/bit.260371109, 1991.

Lindemann, J. and Upper, C. D.: Aerial dispersal of epiphytic bacteria over bean plants, Appl. Environ. Microbiol., 50, 1229-1232, 1985.

Lindemann, J., Constantinidou, H. A., Barchet, W. R., and Upper, C. D.: Plants as sources of airborne bacteria, including ice nucleation-active bacteria, Appl. Environ. Microbiol., 44, 10591063, 1982.

Matthias-Maser, S. and Jaenicke, R.: The size distribution of primary biological aerosol particles with radii $>0.2 \mu \mathrm{m}$ in an urban/rural influenced region, Atmos. Res., 39, 279-286, doi:10.1016/0169-8095(95)00017-8, 1995.
Miquel, P.: Les organismes vivants de l'atmosphere, GauthierVillars, Paris, doi:10.5962/bhl.title.1692, 1883.

Möhler, O., DeMott, P. J., Vali, G., and Levin, Z.: Microbiology and atmospheric processes: the role of biological particles in cloud physics, Biogeosciences, 4, 1059-1071, doi:10.5194/bg-4-10592007, 2007.

Möhler, O., Benz, S., Saathoff, H., Schnaiter, M., Wagner, R., Schneider, J., Walter, S., Ebert, V., and Wagner, S.: The effect of organic coating on the heterogeneous ice nucleation efficiency of mineral dust aerosols, Environ. Res. Lett., 3, doi:10.1088/17489326/3/2/025007, 2008a.

Möhler, O., Georgakopoulos, D. G., Morris, C. E., Benz, S., Ebert, V., Hunsmann, S., Saathoff, H., Schnaiter, M., and Wagner, R.: Heterogeneous ice nucleation activity of bacteria: new laboratory experiments at simulated cloud conditions, Biogeosciences, 5, 1425-1435, doi:10.5194/bg-5-1425-2008, 2008 b.

Morris, C. E., Georgakopoulos, D. G., and Sands, D. C.: Ice nucleation active bacteria and their potential role in precipitation, $\mathrm{J}$. Phys. IV, 121, 87-103, doi:10.1051/jp4:2004121004, 2004.

Morris, C. E., Sands, D. C., Glaux, C., Samsatly, J., Asaad, S., Moukahel, A. R., Gonçalves, F. L. T., and Bigg, E. K.: Urediospores of rust fungi are ice nucleation active at $>-10^{\circ} \mathrm{C}$ and harbor ice nucleation active bacteria, Atmos. Chem. Phys., 13, 4223-4233, doi:10.5194/acp-13-4223-2013, 2013.

Morris, C. E., Conen, F., Huffman, J. A., Philips, V., Pöschl, U., and Sands, D. C.: Bioprecipitation: a feedback cycle linking Earth history, ecosystem dynamics and land use through biological ice nucleators in the atmosphere, Glob. Change Biol., 20, 341-351, doi:10.1111/gcb.12447, 2014.

NATO: Laser based stand-off detection of biological agents, Tech. rep., 2010.

Ortega, J., Turnipseed, A., Guenther, A. B., Karl, T. G., Day, D. A., Gochis, D., Huffman, J. A., Prenni, A. J., Levin, E. J. T., Kreidenweis, S. M., DeMott, P. J., Tobo, Y., Patton, E. G., Hodzic, A., Cui, Y., Harley, P. C., Hornbrook, R. H., Apel, E. C., Monson, R. K., Eller, A. S. D., Greenberg, J. P., Barth, M., CampuzanoJost, P., Palm, B. B., Jimenez, J. L., Aiken, A. C., Dubey, M. K., Geron, C., Offenberg, J., Ryan, M. G., Fornwalt, P. J., Pryor, S. C., Keutsch, F. N., DiGangi, J. P., Chan, A. W. H., Goldstein, A. H., Wolfe, G. M., Kim, S., Kaser, L., Schnitzhofer, R., Hansel, A., Cantrell, C. A., Mauldin III, R. L., and Smith, J. N.: Overview of the Manitou Experimental Forest Observatory: site description and selected science results from 2008-2013, Atmos. Chem. Phys. Discuss., 14, 1647-1709, doi:10.5194/acpd14-1647-2014, 2014.

Pöhlker, C., Wiedemann, K. T., Sinha, B., Shiraiwa, M., Gunthe, S. S., Smith, M., Su, H., Artaxo, P., Chen, Q., Cheng, Y., Elbert, W., Gilles, M. K., Kilcoyne, A. L. D., Moffet, R. C., Weigand, M., Martin, S. T., Pöschl, U., and Andreae, M. O.: Biogenic potassium salt particles as seeds for secondary organic aerosol in the Amazon, Science, 337, 1075-1078, doi:10.1126/science.1223264, 2012.

Pöhlker, C., C., Huffman, J. A., Förster, J.-D., and Pöschl, U.: Autofluorescence of atmospheric bioaerosols: spectral fingerprints and taxonomic trends of pollen, Atmos. Meas. Tech., 13, 33693392, doi:10.5194/amt-6-3369-2013, 2013.

Pope, F. D.: Pollen grains are efficient cloud condensation nuclei, Environ. Res. Lett., 5, 044015, doi:10.1088/17489326/5/4/044015, 2010. 
Pöschl, U., Martin, S. T., Sinha, B., Chen, Q., Gunthe, S. S., Huffman, J. A., Borrmann, S., Farmer, D. K., Garland, R. M., Helas, G., Jimenez, J. L., King, S. M., Manzi, A., Mikhailov, E., Pauliquevis, T., Petters, M. D., Prenni, A. J., Roldin, P., Rose, D., Schneider, J., Su, H., Zorn, S. R., Artaxo, P., and Andreae, M. O.: Rainforest aerosols as biogenic nuclei of clouds and precipitation in the Amazon, Science, 329, 1513-1516, doi:10.1126/science.1191056, 2010.

Pratt, K. A., DeMott, P. J., French, J. R., Wang, Z., Westphal, D. L., Heymsfield, A. J., Twohy, C. H., Prenni, A. J., and Prather, K. A.: In situ detection of biological particles in cloud ice-crystals, Nat. Geosci., 2, 398-401, doi:10.1038/ngeo521, 2009.

Prenni, A. J., Petters, M. D., Kreidenweis, S. M., Heald, C. L., Martin, S. T., Artaxo, P., Garland, R. M., Wollny, A. G., and Pöschl, U.: Relative roles of biogenic emissions and Saharan dust as ice nuclei in the Amazon basin, Nat. Geosci., 2, 402-405, doi:10.1038/ngeo517, 2009.

Prenni, A. J., Tobo, Y., Garcia, E., DeMott, P. J., Huffman, J. A., McCluskey, C. S., Kreidenweis, S. M., Prenni, J. E., Pöhlker, C., and Pöschl, U.: The impact of rain on ice nuclei populations at a forested site in Colorado, Geophys. Res. Lett., 40, 227-231, doi:10.1029/2012GL053953, 2013.

Pringle, A., Patek, S. N., Fischer, M., Stolze, J., and Money, N. P.: The captured launch of a ballistospore, Mycologia, 97, 866-871, doi:10.3852/mycologia.97.4.866, 2005.

Pummer, B. G., Atanasova, L., Bauer, H., Bernardi, J., Druzhinina, I. S., Fröhlich-Nowoisky, J., and Grothe, H.: Spores of many common airborne fungi reveal no ice nucleation activity in oil immersion freezing experiments, Biogeosciences, 10, 80838091, doi:10.5194/bg-10-8083-2013, 2013.

Robinson, N. H., Allan, J. D., Huffman, J. A., Kaye, P. H., Foot, V. E., and Gallagher, M.: Cluster analysis of WIBS single-particle bioaerosol data, Atmos. Meas. Tech., 6, 337-347, doi:10.5194/amt-6-337-2013, 2013.

Santarpia, J. L., Pan, Y.-L., Hill, S. C., Baker, N., Cottrell, B., McKee, L., Ratnesar-Shumate, S., and Pinnick, R. G.: Changes in fluorescence spectra of bioaerosols exposed to ozone in a laboratory reaction chamber to simulate atmospheric aging, Opt. Express, 20, 29867-29881, doi:10.1364/OE.20.029867, 2012.

Šantl Temkiv, T., Finster, K., Dittmar, T., Hansen, B. M., Thyrhaug, R., Nielsen, N. W., and Karlson, U. G.: Hailstones: a window into the microbial and chemical inventory of a storm cloud, PLOS ONE, 8, e53550, doi:10.1371/journal.pone.0053550, 2013.
Schumacher, C. J., Pöhlker, C., Aalto, P., Hiltunen, V., Petäjä, T., Kulmala, M., Pöschl, U. and Huffman, J. A.: Seasonal cycles of fluorescent biological aerosol particles in boreal and semi-arid forests of Finland and Colorado, Atmos. Chem. Phys., 13, 11987-12001, 10, http://www.atmos-chem-phys.net/13/11987/10/.5194/acp-1311987-2013, 2013.

Sesartic, A., Lohmann, U., and Storelvmo, T.: Modelling the impact of fungal spore ice nuclei on clouds and precipitation, Environ. Res. Lett., 8, 014029, doi:10.1088/1748-9326/8/1/014029, 2013.

Sivaprakasam, V., Huston, A. L., Scotto, C., and Eversole, J. D.: Multiple UV wavelength excitation and fluorescence of bioaerosols, Opt. Express, 12, 4457, doi:10.1364/OPEX.12.004457, 2004.

Smith, D. J. and Griffin, D. W.: Inadequate methods and questionable conclusions in atmospheric life study, P. Natl. Acad. Sci USA, 110, E2084, doi:10.1073/pnas.1302612110, 2013.

Stanley, W. R., Kaye, P. H., Foot, V. E., Barrington, S. J., Gallagher, M., and Gabey, A.: Continuous bioaerosol monitoring in a tropical environment using a UV fluorescence particle spectrometer, Atmos. Sci. Lett., 12, 195-199, doi:10.1002/as1.310, 2011.

Stepanov, K.: Stepanov, Dissemination of infective diseases of plants by air currents, Bull. Plant Prot. Leningrad Phytopathol., 8, 1-68, 1935.

Sullivan, R. C., Petters, M. D., DeMott, P. J., Kreidenweis, S. M., Wex, H., Niedermeier, D., Hartmann, S., Clauss, T., Stratmann, F., Reitz, P., Schneider, J., and Sierau, B.: Irreversible loss of ice nucleation active sites in mineral dust particles caused by sulphuric acid condensation, Atmos. Chem. Phys., 10, 1147111487, doi:10.5194/acp-10-11471-2010, 2010.

Tack, A. J. M., Hakala, J., Petäjä, T., Kulmala, M., and Laine, A.: Genotype and spatial structure shape pathogen dispersal and disease dynamics at small spatial scales, Ecology, 95, 703-714, doi:10.1890/13-0518.1, 2014

Tobo, Y., Prenni, A. J., DeMott, P. J., Huffman, J. A., McCluskey, C. S., Tian, G., Pöhlker, C., Pöschl, U., and Kreidenweis, S. M.: Biological aerosol particles as a key determinant of ice nuclei populations in a forest ecosystem, J. Geophys. Res.Atmos., 118, 10100-10110, doi:10.1002/jgrd.50801, 2013.

Toprak, E. and Schnaiter, M.: Fluorescent biological aerosol particles measured with the Waveband Integrated Bioaerosol Sensor WIBS-4: laboratory tests combined with a one year field study, Atmos. Chem. Phys., 13, 225-243, doi:10.5194/acp-13225-2013, 2013. 